\title{
Ein Fragment aus dem Psalmen-Commentar des Tanhûum aus Jerusalem.
}

Herausgegeben und bearbeitet von Rabb. Dr. S. Eppenstein, Briesen, Wpr

Der vorliegende fragmentarische Commentar $\mathrm{zu}$ den Psalmen stammt aus dem Ms. No. 3676 der Kaiserl. Oeffentlichen. Bibliothek zu St. Petersburg. Als Verfasser desselben kann nur Tanhûum aus Jerusalem in Betracht kommen, wie bereits von Poznański in ZHB V p. I24ff. nachgewiesen ist, wo derselbe auch einige Mitteilungen aus der Handschrift gemacht hat. $\mathrm{Zu}$ den dort gegebenen Nachweisen füge ich noch hinzu: Das Vorkommen des term. אלח zu 27,8, der bei den jüd.-arabischen Schriftstellern nur von Maimûni und nach ihm von Tanhụum angewendet wird. Auch die philosophische Erklärung des Cap. 29 weist ganz auf den Einfluss Maimûni's hin, so dass auch nur die Zeit Tanbûm's in Betracht kommen kann. Ausserdem zeigen sich auch Spuren von Übereinstimmungen mit David Kimhi, dessen Benutzung durch Tanhûm sich nicht bestreiten lässt ${ }^{x}$. - Indem ïch nun zur Veröffentlichung des Fragmentes schreite, bemerke ich noch, dass ich zur Herstellung des Textes auf eine durchaus nicht zuverlässige Abschrift angewiesen war, so dass ich manches combinieren musste ${ }^{2}$. Vielen Dank schulde ich in erster Reihe meinem geehrten Freunde, Herrn Dr. Poznański-Warschau, der die für ihn gefertigte Copie mit grosser Freundlichkeit mir überliess, und mir auch manche Belehrung zukommen liess, ferner Herrn Prof. v. Kokowzoff-St. Petersburg, der sich in anerkennenswertem Entgegenkommen der Mühe unterzog, einige Stellen des Ms., besonders das arg verstümmelte Cap. 22, für mich zu collationieren.

I Vgl über diesen Punkt noch Poznański, RdEJ XL p. 133.

2 Die Verbesserungen, die sich mit denen Goldziher's in Poznańki's 
Cap. $x 6$.

.... So wie wir es in Ps. I I, 6 erklärt haben; gemeint ist ,mein Anteil", indem מנת aufzufassen ist, wie מנה in Lev. 8, 21. חלקי ist wie in Gen. 14, 15, Deut. 32, 9, Jer. 10, 16. כוסי ist wie תxוסו in Exod. 12, 4 ,ihr sollt unter einander teilen", und wie במכסת ibid. ${ }^{x}$. Manche übersetzen כוסי mit iضn ,guter Anteil"; so wird es auch Ps. 23, 6 übersetzt: „mein Glück ist voll“" . Nach einigen bedeutet es dort auch Becher, wie in. Gen. 40, II, so dass gemeint ist: mein Becher ist voll; ebenso auch כוס in Ps. I16, 13, wo es aber auch den Sinn von wie in Gen. 48, 17, Prov. 31, 19; es ist ein Particip, das eigentlich, wie עומר עוצר, mit Zere lauten sollte und, Chirek hat wie eine Hiphilform. Die Unregelmässig. keit hierbei ist wie bei $7^{\prime D}$ in Jes. 29, I4, das eigentlich eine Kalform ist und wie eine Hiphilform lautet, also gleich מוסיך. V. 6 תבלים bedeutet Teile Landes, wie חבל ist wie Los, und deswegen wird es damit bezeichnet, weil die Ländereien mit Messschnuren gemessen werden, zwecks

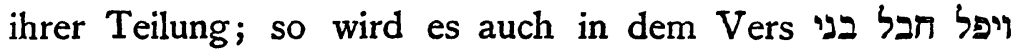
3 ๆ0l' angewendet, indem dieselbe Übertragung stattfindet. בנעימים hat die Bedeutung ,Lust, Vergnügen“; der Dichter weist jedoch damit hin, dass er sein Glück und Los nicht findet in der sinnlichen, hinfälligen Welt mit ihren gleichfalls aufhörenden Vergnügungen und ihrem vergänglichen Glück, vielmehr ist sein Streben, Glück und Los in der erhabenen, göttlichen Welt, die nicht unsicher ${ }^{4}$ und

Artikel ZHB. 1. c. p. 185 berühren, habe ich selbst, bevor mir jene zu Händen kamen, gefunden.

I So leitet es auch Saadia in Ps. I1, 6 ab (ed. Margulies p. I3), צ's, während er es hier durch ימפת מן במכסת נפשות ,mein Verdienst" wiedergiebt (ibid. p. I 7). 


\section{Cap. 16.}

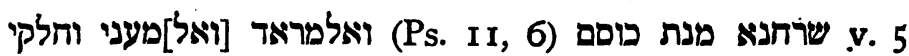

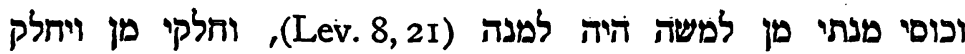

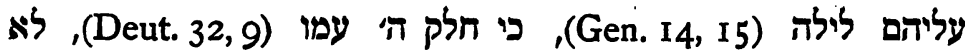

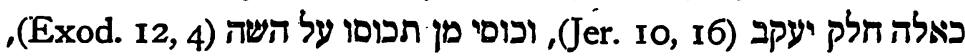

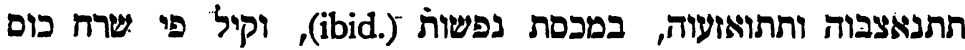

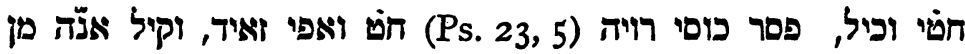

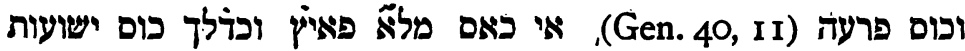

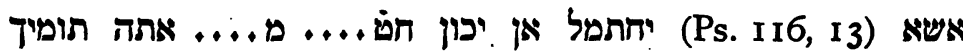

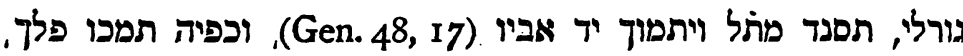

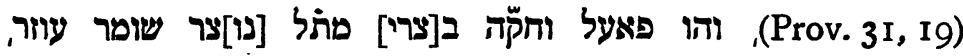

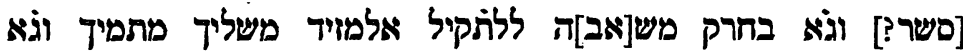

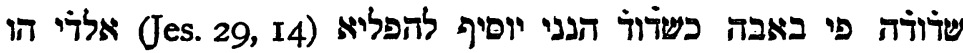

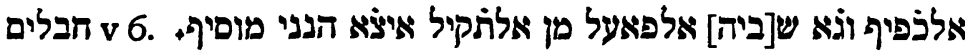

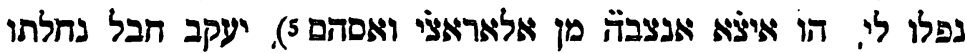
(Deut. 32,9)

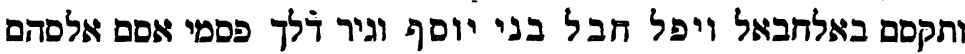

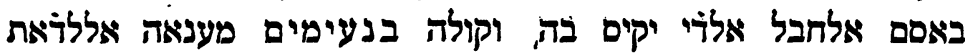

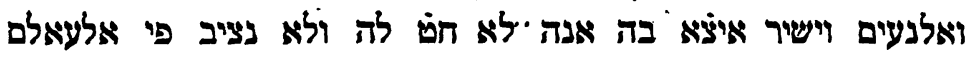

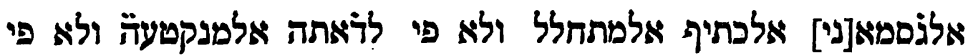

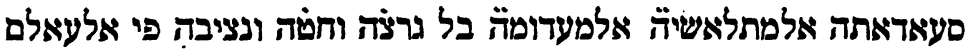

2 Ganz so haben auch Saadia a. 1. (vgl. S. Lehmann, Saadia AlFajûmis arab. Psalmenübersetzung u. Comm. Ps. 2I-4I, Berlin 190I, p. V) und Ibn Ģanâh Wb. 312, 34; jedoch heisst es bei beiden statt ואפי ואר ואר ואי ואי Tie Übersetzung Juda Ibn Tibbon's, ed. Bacher p. 216 חלקי הנדול giebt nicht ganz genau die Ansicht Ibn Ganâh's wieder.

3 Ein derartiger Vers in der Bibel ist mir unauffindbar; vielleicht hatte T. im Sinn Jos, 17, 5: ויפלו חבלי מנשה. Über ungenaue Citate bei T. vgl. Goldziher, Studien über Tanḥum Jeruschalmi p. 34-35.

4 Unseres Erachtens lässt sich טרכّ hier nur in diesem Sinn auffassen.

5 Mit aTD giebt es auch wieder Saadia a. 1. (1. c. p. 17).

Zeitschrift f. d. alttest. Wiss. Jahrg. 23. II. 1903. 
vergänglich ist, in der geistigen Welt, deren Vergnügungen ewig, und deren Glück dauernd, wie wir auch an einer anderen Stelle bereits bemerkt haben, dass man das Wort ay vielfach in diesem Sinn braucht ${ }^{x}$.

\section{Cap. 17 .}

v. 3. Das Schlechte findet sich nicht in seinen innersten Gedanken, geschweige denn, dass er es ausspricht, oder gar thut. v. 4. שמרתי hat hier den Sinn von משמרתי ,ich habe mich gehütet vor u. s. w." ${ }^{2}$, indem er sagen will: ich sah Menschen, welche grade das Gegenteil deiner Befehle thaten und deine Gesetze ausser Acht liessen, und so hütete ich mich vor den Wegen der Gottlosen und Schamlosen, um ihnen nicht in in ihrem Thun zu gleichen und nicht von ihren Eigenschaften zu lernen. Unter טריצים sind die Schamlosen zu verstehen, welche rauben und öffentlich Zuchtlosigkeit, Gewaltthat, kurz alles Schlechte verüben, ohne es zu verheimlichen. So wird das Wort auch gebraucht in I Sam. 25, Io, ähnlich auch in Hosea 4, 2, wo der Sinn ist: sie sind schamlos, begehen öffentliche Widerspenstigkeiten und vergiessen offenkundig das Blut ihrer Nebenmenschen. Das Wort פרץ wird auch im Sinn von ,hervortreten" und ,sich ausbreiten" angewendet, wie Gen. 3.0, 43, Jes. 54, 3, Hiob I, IO. v. 5. ritum, wie Jud 15,2, Jer. 3I, 18. Für die Verbindung mit dem Futurum vergleiche Echa 3, 20, Jer. 25, 28. Hingegen ist es in Deut. 16, I und 15, 12 als Imperativ aufzufassen. In allen oben genannten Fällen ișt noch ein Verbum hinzuzudenken, sei es, dass es vorangeht oder nachfolgt. Beispiele für ersteres sind: Jud. 4, 9, Num. 22, 37, Echa 3, 20, Jer. 3I, 18, I Reg. 8, I3, Echa I, 2, Exod. 22, 22. Beispiele für die Nachstellung des Infinitiv sind Gen. 26, I3,

I Vgl. zu diesen Ausführungen die Bemerkung David Kimhi's im Comm. a. 1. וברעות טובות ונכונות. 


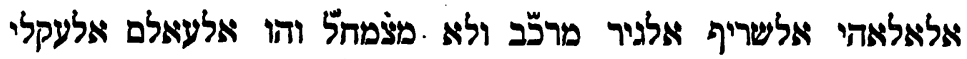

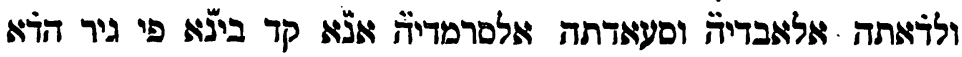
הלמוצע באן אכתר תצריף לגה נעים אנמאו...

\section{Cap. I7.}

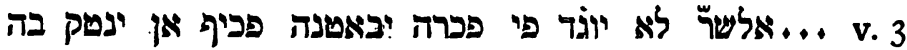

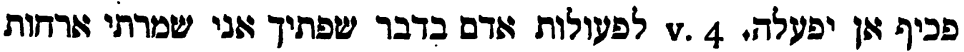

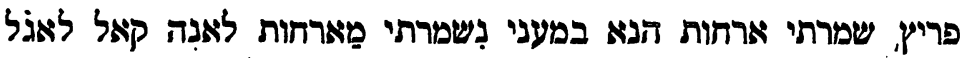

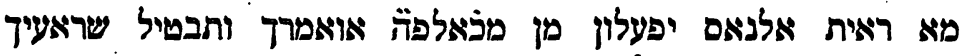

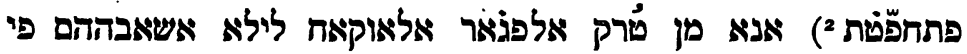

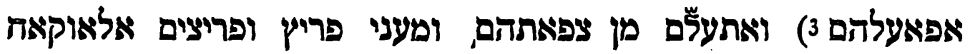

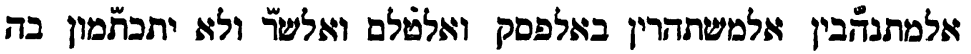

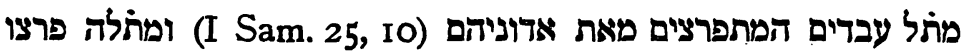

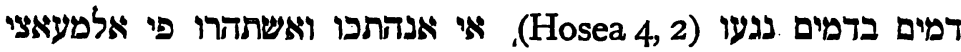

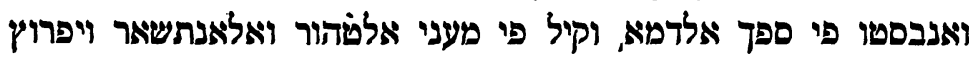

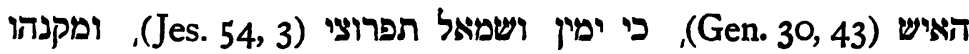
פרץ בארץ (Hiob I, I0). 5 (G. 5 תמוך אשורי במעגלותיך, תמוך מצדר

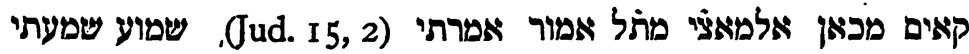

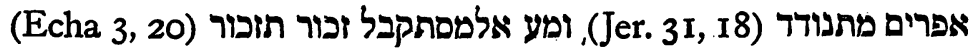

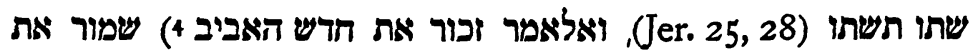

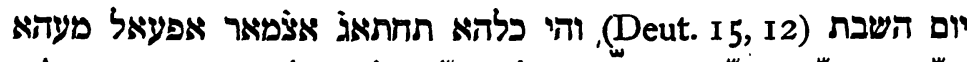

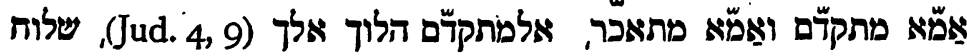

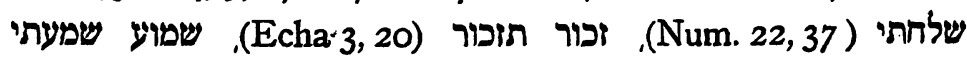
(Echa I, 2) (Jer.3I, I8)

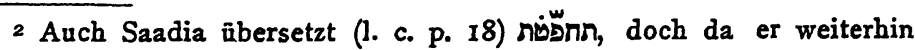
sagt בסבל, ist es fraglich, ob die Wiedergabe von Margulies 1. c. p. $3^{8}$ „,ich habe mich vor den Wegen u. s. w. gehütet“ richtig ist, da es alsdann hätte heissen müssen $u_{0}$ nicht 2 . Vielleicht meint Saadia, wie auch Raschi a. 1.: ich beobachtete die Wege der Frevler, um nicht ihre Thaten zu begehen.

3 Unsere Vorlage hat hier eine Verstümmelung, die jedoch nur so $2 u$ lesen ist.

4 Jedenfalls ist hier gemeint שמור את חרש Deut. 16, I. 
ibid. 8, 7. Das Auslassen des verbum finitum ist eine Abkürzung behufs Erleichterung; so ist es bei allen diesen Infinitiven, so dass ein verbum finitum ergänzt werden muss; hier also musste der Satz vollständig lauten: תמוך תמכו אשורי

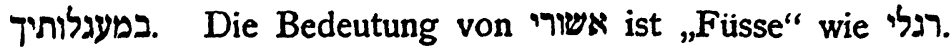

Cap. I8.

v. 43. טיט חוצות bedeutet den Kot der Märkte, oder der engeren Strassen, so übersetzt auch Onkelos חin in Gen. 39, 12 mit שוש, auch Jer. 37, 21 bedeutet es „Markt der Brotverkäufer". Betreffs אריק ist die Erklärung, wonach es gleich sei, richtig, wie auch die gleiche Bedeutung beider aus dem Vers Exod. 30, 36 hervorgeht ${ }^{x}$.

v. 45. 'ישמעו bedeutet: sie gehorchen mir, schon beim Hören, auch wenn sie nicht bis zu mir gelangt sind und mich sehen, infolge ihrer grossen Furcht und ihres Schreckens vor mir. Denselben Sinn hat משמעת in Jes. II, I4 und II Sam. 23, 23, wo es bedeutet, ,die ihm unterthan sind". Das Dagesch in ישמעו ist eine Folge des Nun des Niphal. יכחשו לי bedeutet: sie erniedrigen und beugen sich vor mir. Eigentlich sollte das Wort im Hithpael oder Niphal gebraucht sein, wie Deut. 33, 29, wo das Nun des Niphal oder Taw des Hithpael im Kaf aufgegangen ist, indes genügt auch diese Form, da das Verbum intransitiv ist, so dass es jenen beiden Formen in der Bedeutung gleichkommt; ebenso ist es in Ps. 66, 6. v. 46. י ירולו bedeutet eigentlich "fallen", wie in Exod. 18, 18, Ez. 47, 12. Für erstere Stelle bemerkt Saadia, dass man sie, in übertragenem Sinn und aus geziemender Ehrfurcht vor Mosche,

I Aus der Anführung dieses Beispieles ist zu schliessen, dass Tanhum hier an das in der Parallelstelle II Sam. 22, 43 gebrauchte op hat. Die hier von Tanhum angeführte Ansicht ist wol die Saadia's, der das Wort an unserer Stelle mit im Text gebrauchite תכויר ist uns unverständlich; es könnte höchstens 


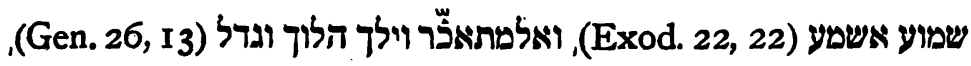

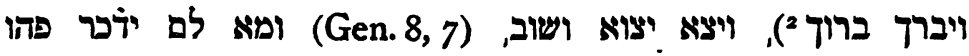

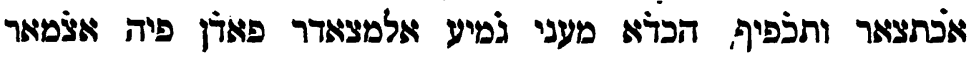
תמוך תמכו אשורי במעגלותיך. ואשורי הקדיאמי כמא קצאל.

- Cap. 18.

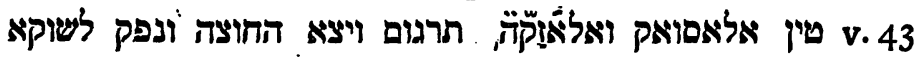
(Gen. 39, I2)

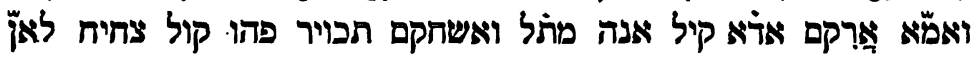

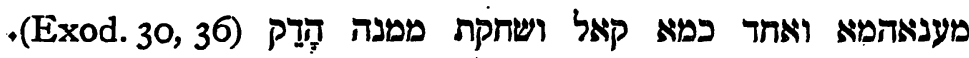
v. 45

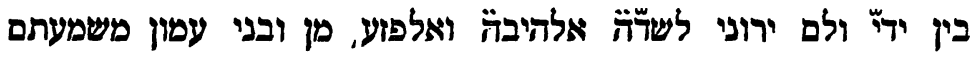

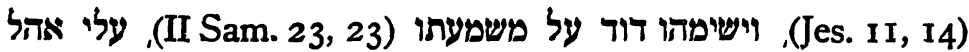

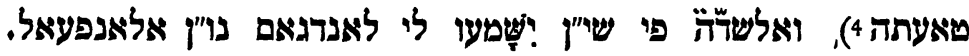

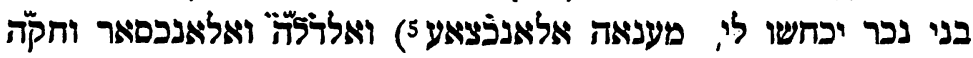

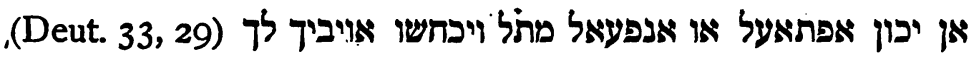

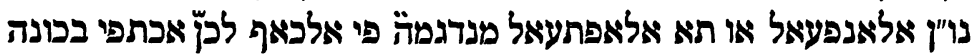

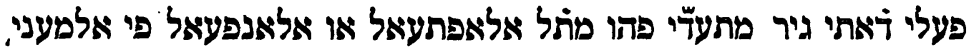

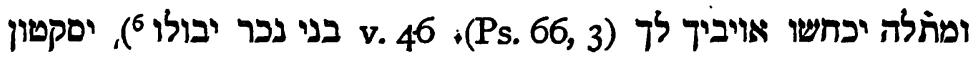

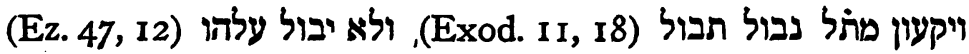

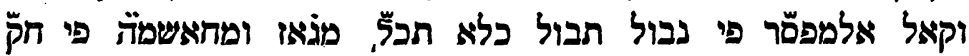

hier die Bedeutung haben: niederstrecken. Herr Dr. Poznański schlägt

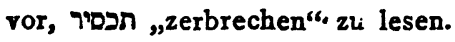

2 Ein solcher Vers ist nicht zu finden.

3 So ist wol sicher 2 u lesen anstatt des Mispis der Vorlage.

4 Diese Stelle teilt auch mit Pozn. ZHB. 1. c. p. 126. Vgl. auch Tanḥum zu II Sam. 23, 23, ed. Haarbrücker, p. 54-6o, u. Ibn G̣anâh Wb 732, 33. Zu Jes. II, I4 vgl. auch Saadia a. 1. (ed. Derbg. p. 19).

5 Denselben Ausdruck hat auch Saadia zu Ps. 66, 3 (ed. Baron, Berl. 1900, p. XVI).

6 Diese Stelle vgl. bei Pozn. 1. c. p. 124, wo auch darauf hin-

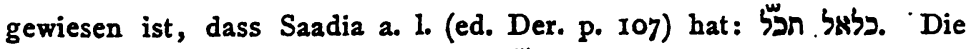
Veranlassung zur Wahl des Wortes לّ für upo mag wohl sein, dass arab. upo, gleich hebr. לב, vom gefallenen Tier angewendet wird. 
dem Gesandten Gottes, mit "כל כת „schwach werden“ über setzen muss, um von ihm nicht den Ausdru ck,,Fallen" anzuwenden. Eigentlich aber bedeutet das Wort, sonst, wo es vorkommt, „Niederfallen, Abfallen". ויחרגו ist wiederzugeben mit "hinken" infolge der schweren Ketten. Es ist eine Umstellung von ויחג, das abzuleiten ist von welches dem arab. אער ה entspricht, wie auch Onkelos Lev. 21, 18 mit חגירא wiedergiebt. מסגרותיהם hat in sich die Bedeutung o schliessen, wie in Gen. 19, 6, İ Reg. 5, 21 , Koh. 12, 4, dann ist es auch übertragen worden auf das Gefängnis, wie in Jes. 42, 7. Hier sind wohl noch gemeint die Ketten, die den Menschen hindern, sich auch seinem Willen und seiner Wahl zu bewegen. Es ist dann zusammenzustellen mit סוגר Ez. I9, 9, das R'Hai im Hâwi durch das arab. wiedergiebt im Sinne einer um den Hals gelegten Kette. Nach anderen bedeutet ויחרגו hier: sie zittern in ihren Ringplätzen, und zwar infolge der Furcht, die sie trifft, wie dies aus v. 45 hervorgeht. In diesem Falle ist das Wort auch her-

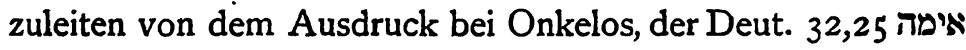
mit יהרגו Todesfurcht" übersetzt, so dass alsodeutet: sie zittern und sind vor Furcht niedergeschlagen.

v. 48. מאויבי ist so viel wie באויבי ,an meinen Feinden“, und 'ל bedeutet hier "für mich, um meinetwillen", wie Gen. 20, I3, ibid. 4I, 55. Für וידבר lautet eine Erklärung: der an der Spitze der Völker steht und sie führt nach meiner Bestimmung ${ }^{x}$. So giebt es auch Onkelos wieder mit רבד im Sinne von führen Gen. 31, 18, Exod. 13, I7.ibid. I5, I3. תחתי bedeutet dann soviel -xie ברגלי, in meinem Gefolge‘

I Eine solche Ansicht citiert Ishâk ibn Barûn in einem neu aufgefundenen Fragment seiner Muwâzana im Namen Mose ibn Chiqitilla's. Das Original der Stelle teilt Poznański mit in seinem: Tanhoum Yerouschalmi et son commentaire sur le livre de Jonas Paris 1900 p. 5 


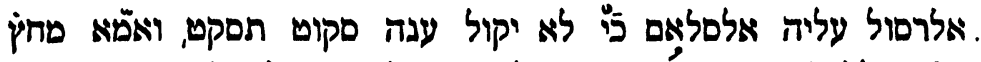

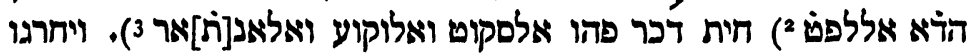

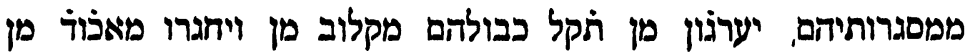

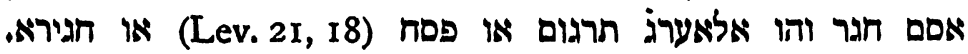

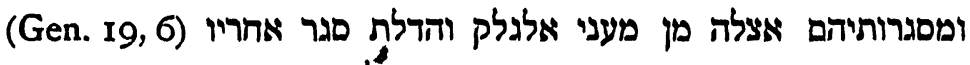

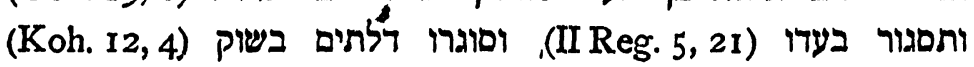

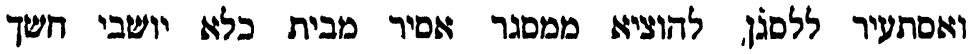

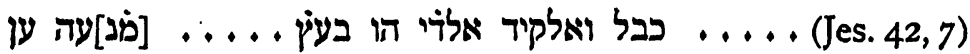

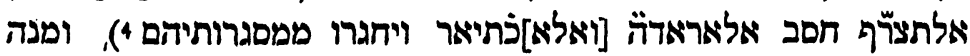

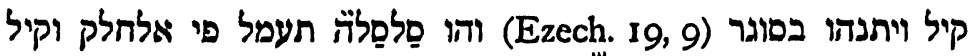

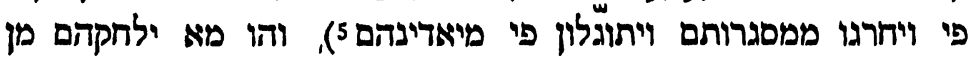

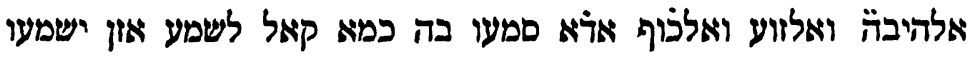
לי וֹללך מן קול אלתרגום איצ's פי פי ומחדרים אימה

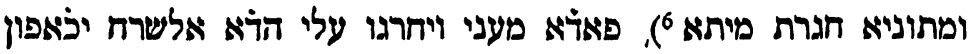

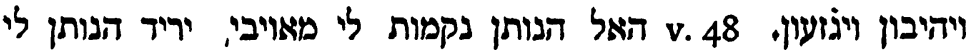

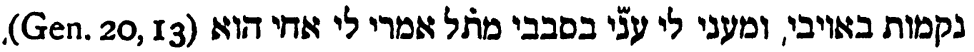

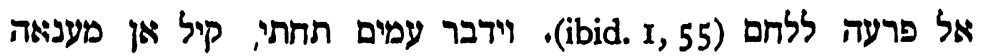

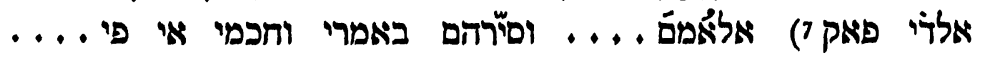

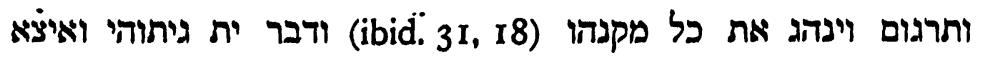

Anm. 4 (S.A aus RdEJ XI). Vgl. auch die erste Erklärung bei Dav. Kimḅi a. l., der jed. vת anders auffasst.

= Dieser Wendung bedient sich S. auch sonst; vgl. Poznariski ZHB l. c. p. 126; sie kommt auck. vor in $R g$ gei Ibn Canâch Wb 66 s. v מהל.

3 So will hier Poznański, 1. c. p 124, lesen.

4 Die folgende Stelle teilt auch Poznański, ibid. mit. Das Citat aus Haî hat ausser Ibn Ganâh Wb. 474, 31-32, noch Ibn Bárún, Muwazana s. v. jedoch ohne Haî zu nennen.

5 Zu ו" ו"תĭ vgl. Margulies, 1. c. p. 46,7 der deutschen Übersetzung Anm. 2. Aus der Schreibung מיכזיכה in der Vorlage will Pozn. 1. c. p. 125 Anm. I schliessen, dass Tanhûum Saadias Comm, in arab. Schrift vorgelegen hat; doch mag dies wohl nur auf einem Fchler des Copisten beruhen, da es cin Wort Dra'b nicht giebt.

6 Das ist ganz nach Saadia; vgl. ed. Margulies p. 21.

7 Dieses Wort ist mir hier unverständlich. 
d. h. die Völker müssen sich in Gehorsam von ihm leiten lassen und seinem Befehle folgen. Nach anderen bedeutet es: er lässt die Völker dahinschwinden an unserer Stelle, in demselben $\operatorname{Sinn}$ wie in Jes. 43, 4. Es wird dann von רב im Sinne von "vernichten" abgeleitet, wie in II Chron. 22, 10 wo ות ותאבד in der Parallelstelle II Reg. 11, I entspricht. ת תחת hat dann dieselbe Bedeutung wie in Exod. 21, 13, Jes. 60, 17 ,anstatt". Von diesen beiden möglichen Erklärungen ist jedoch richtiger die erstere, da mit dieser übereinstimmt die Stelle Ps. 47, 4, wo nחת gleich in unserem Gefolge", wie es auch aus ברגליך, Exod. II, 9 hervorgeht. v. 49. Einige sagen, dass ש's, obwohl Singular, einen Plural bedeutet, und dass gemeint ist מאנשי דמים: von Männern der Blutschuld und das sind diejenigen, von denen der Dichter im Anfang des Verses spricht, wie auch sonst der ganze Psalm von mehreren Gegnern spricht ${ }^{2}$. Nach anderen ist aber hier wirklich an eine einzelne Person gedacht und zwar an Saul3, der auch im Anfang des Psalmes unter den Feinden genannt wird. Diesen hebt er auch hier hervor nach Erwähnung seiner Feinde, sowie er es dort gethan. Er nennt ihn „,einen gewaltthätigen Mann, der ihn zu töten versuchte und mit Gewalt gegen ihn vorging, ohne dass er gegen Saul gesündigt und sich vergangen, indem er vielmehr ihm Gutes erwiesen, ihm gedient hat und treu $\mathrm{zu}$ ihm war. Jener aber hat es ihm schlecht gelohnt, ihn verfolgt, war hart zu ihm und vertrieb ihn, ja, wenn er seiner habhaft geworden wäre, hätte er ihn getötet; das ist jedenfalls Gewaltthat und Unrecht. So erwähnt denn der Dichter zuerst seine Feinde überhaupt, von denen er in v. I und in diesem Vers spricht, wobei תרוממני aufzufassen ist, dann hebt er im einzelnen besonders Saul hervor, wie in v. I. תצילני ist auch wie ein Präteritum4. Alsdann dankt er Gott 
נחית בחסדך (Exod. 15, 13) דברת בטבוותך ועיניא ולא נחם המלהים

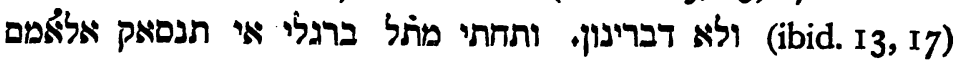

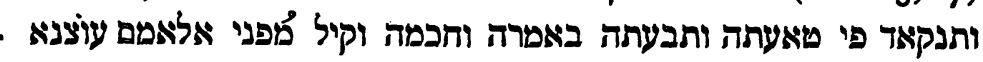

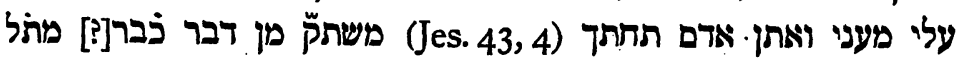

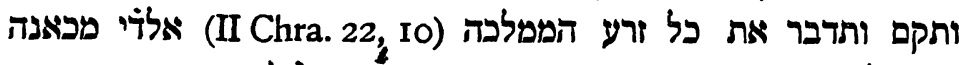

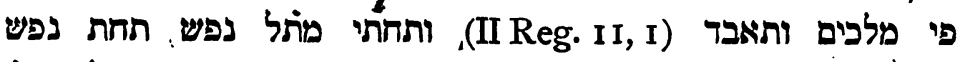

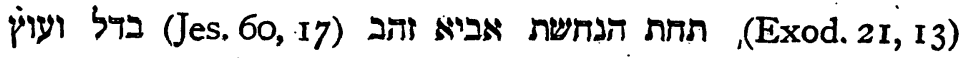

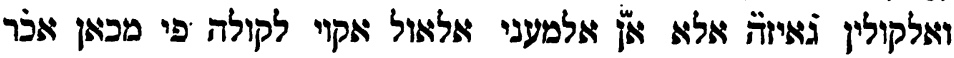

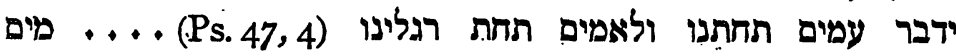

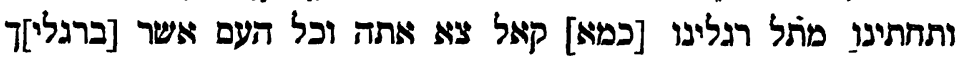

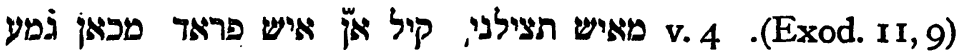

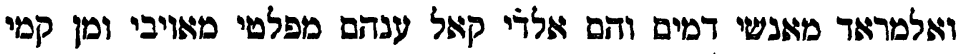

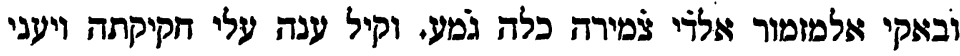

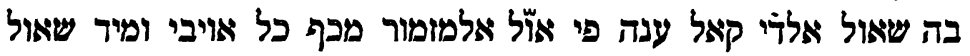

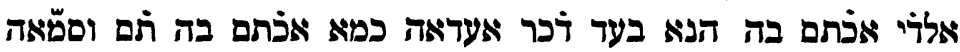

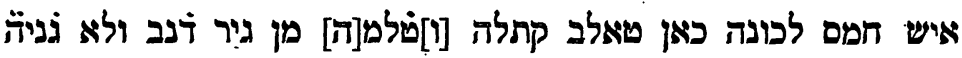

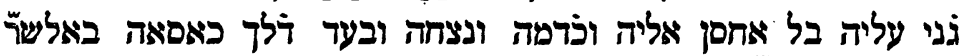

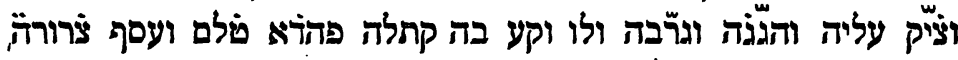

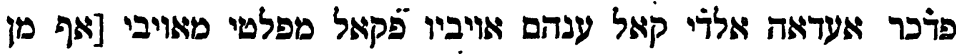

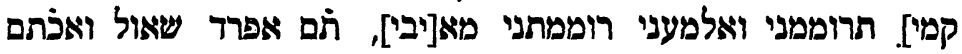

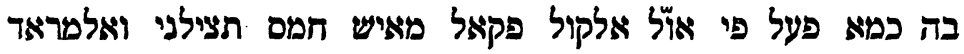

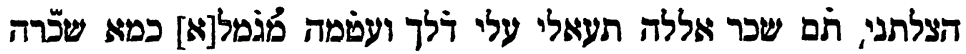

I Vgl. auch IG̣. Wb. 152, 4-II. Der dort $Z_{5}$, angewendete Ausdruck bsis findet sich auch bei Saadia an unserer Stelle, der es mit לร̆ übersetzt (ed. Marg. 1. c.), während er es zu Ps. 46, 4, (ed. Hofmann, Ehingen 1890 p. 4) mit ידָ ,er demütigt" wiedergiebt. Mit IG̣ stimmt auch überein Ibn Barûn's eigene Erklärung in der oben erwähnten Stelle des handschriftlichen Fragmentes, die laut freundlicher Mitteilung des

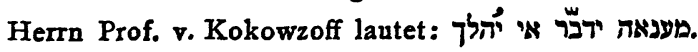

2 Vielleicht ist hier Saadia gemeint, der hier ï übersetzt.

3 Vgl. auch Abr. ibn Esra u. Dav. Kimḥi a. 1.

4 Vgl. auch David Kimpi. 
hierfür und preist ihn ganz besonders wie im Eingang des Psalmes. אורד ist das Futur von der Hiphilform הוiד, wie יהודור Ps. 45, 18, I1, 17. Wir haben bereits erwähnt, dass dieses Wort mitunter bedeutet: Dank für bereits erwiesene Wohlthaten, wie an den erwähnten Stellen und Ps. 1 18, 21, dann aber auch Lob und Preis, der Gott seinem Wesen nach zukommt, wie Ps. II8, I und noch an vielen anderen Stellen ${ }^{x}$. v. 51. מגדיל ist ein Particip Hiphil; es bedeutet: er macht gross seine Hilfe und seine Befreiung, und lässt ihm.viel Unterstützung $z u$ teil werden. In der Parallelstelle II Sam. 22, 5 I heisst es מנדול, womit eine Burg, ein Festungsthurm gemeint ist, wie מגדול in Prov. 18, 10, und zwar in dem Sinne, dass auf Gott die Stärke seiner Herrschaft und die Hilfe seines Gesalbten, wie dessen Befreiung beruht. מגדול bedeutet demnach dasselbe, wie

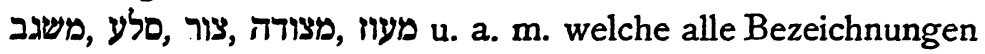
sind für feste Burgen und hohe feste Punkte, von denen aus man die Feinde überschauen kann, und zu denen man in der Angst bei Unglücksfällen und Krieg flüchten kann, so dass man von Bösem bewahrt bleibt. Hier ist das Wort in erweitertem Sinn auf Gott übertragen, der seine wirkliche Zuflucht und sein Schutz ist für den, der zu ihm seine Zuflucht nimmt und auf ihn sich stützt. - Unter משיחו ist der König zu verstehen ${ }^{2}$; allerdings ist darin eine Wiederholung und verstärkende Erklärung enthalten für die Worte ישועות מלכו' Dann bemerkt er ausdrücklich in den Worten לדוד ולזרעו, dass damit David und alle seine Nachfolger gemeint sind. Mit den Worten עולד על על על weist er darauf hin, dass die Wurzeln seiner Herrschaft nie aufhören, und seine Nachkommen bis in Ewigkeit nicht verschwinden sollen. Unsere Lehrer fassen מגדל ישועות als auf David be-

I Vgl. hierzu die Ausführungen Saadia's im Comm. zu Jes. $6 \hat{j}, 7$ 


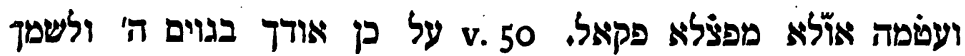

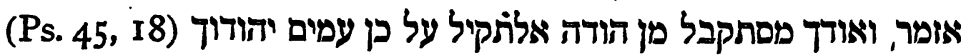

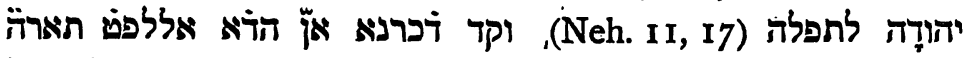

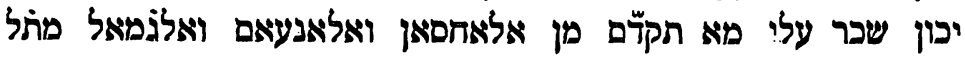

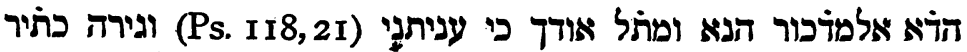

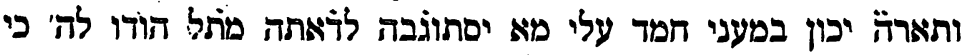

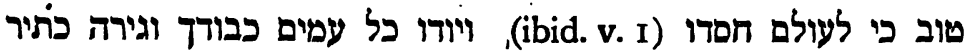

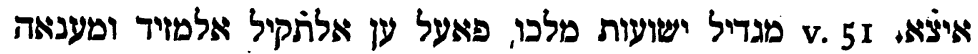

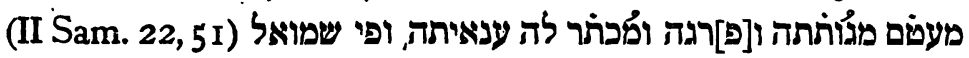

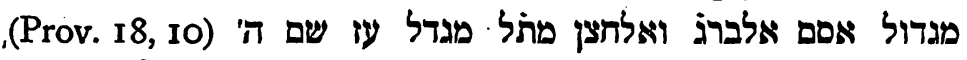

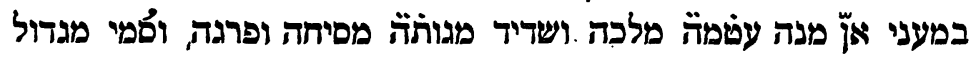

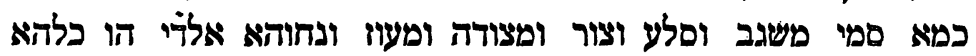

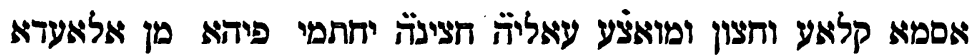

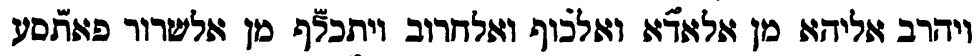

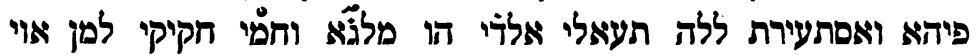

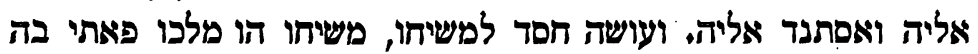

(ed. Der., p. 143), wo er in derselben Bedeutung das arab. 7ññ im Gegensatz zu שודאה im erklärt, und bemerkt, dass auch. sowohl Dank für erwiesene Wohlthaten, als auch Lobpreisung für den, der es verdient, bedeutet: פניל אלמתמוד פי נפסה. Interessant ist hierfür auch die Bemerkung Saadia's im Comm. zu Ps. 75, 2 betreff des doppelten (Ms. der Kgl. Hof- und Staatsbibliothek zu Mũnchen, cod. arab. 236 fol.

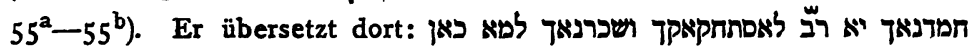
זיב

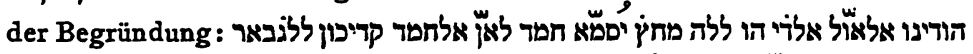

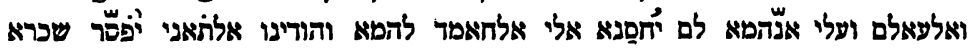
הודן אלשכר אנממא יכון עלי אפצוצאל ואחסאן Gott bezieht, wird durch Allwissenden und Allmächtigen, wenn auch durch beide Eigenschaften dem, der sie preist, keine Wohlthaten erwiesen werden, d. 2. הודינו bedeutet Dank für Wohlthaten.

2 Vgl. auch die Bemerkung Dav. Kimbi's a. 1. מלכו ומשיחו הוא אומר על פצממו 
züglich auf, hingegen beziehen sie עושה חסר למשיחו auf den zu erwartenden Gesalbten, der sich bald offenbaren möge; deswegen wird der Sinn nachher mit den Worten לדוד erläutert.

\section{Cap. 19.}

v. I. Wir haben bereits wiederholt bemerkt, dass unter zu verstehen ist, der Anführer der Leviten und Sänger, besonders der, der das Lied anstimmt und sie lehrt...

\section{Cap. 22.}

v. 4. Das Dagesch in תהלות תהל וst wegen des Ausfalles des zweiten 'ל, da es von dem verb. gemin. הלל

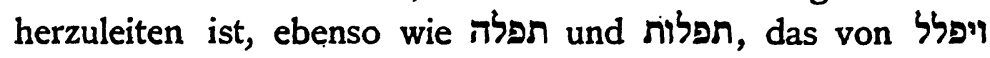
in Ps. 106, 30 abzuleiten ist. Der Sinn des Verses ist: Und du Heiliger, der Du thronst über der Heiligung und Lobpreisung für immer, und der Du zu Israel in einer immerwährenden, festen, nicht endenwollenden Beziehung stehst, und auch das Lob, das Du ihnen zuerst gespendet hast, ist ein immer dauerndes, und Israel vertraut auf Dich, wie man auf einen Vater vertraut; so hilf ihnen denn, und rette sie, und beschäme sie nicht, wie Du auch ihre Väter nicht beschämt hast ${ }^{x}$. v. 5. Vor בשר ist, so dass dieser Vers dem Sinne nach sich an den vorangehenden anschliesst, d. h. Du bist es ja, auf den sie vertraut und sich gestützt haben, und so bist $\mathrm{Du}$ auch es, auf den wir vertrauen, und darum thue uns, wie $\mathrm{Du}$ mit ihnen gethan. v. 7. Der Sinn ist: unseren Vätern hast $\mathrm{Du}$. geholfen und hast sie befreit von ihren Feinden, hast sie vor deren bösen Anschlägen bewahrt; aber uns hast $\mathrm{Du}$ verlassen, so dass wir erniedrigt, vermindert, verachtet hintangesetzt und verspottet unter den anderen Völkern sind, ja wir sind wie Würmer, die niemand beachtet. Der Vers kann auch bezogen werden auf die Seele des Menschen ${ }^{2}$. Denn die 


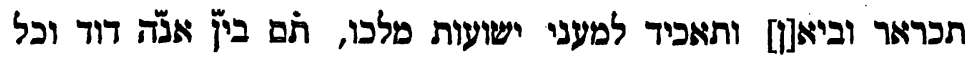

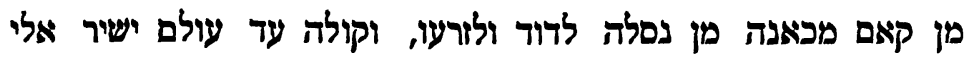

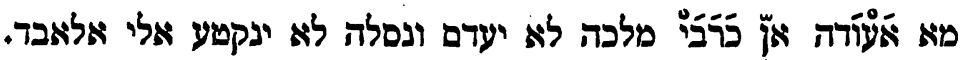

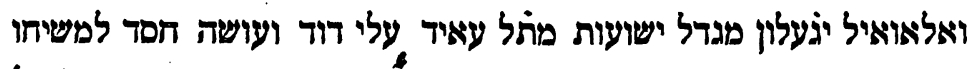

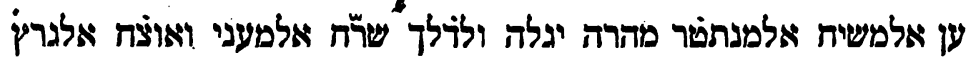
וקהל לדוד ולזרעו עד עולם.

Cap. rg.

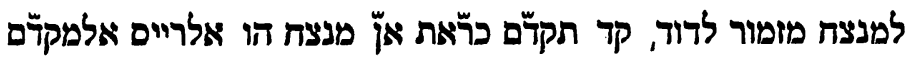

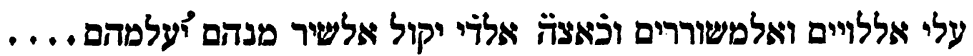

\section{Cap. 22.}

v. 4

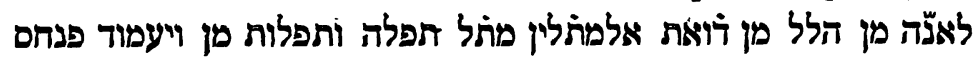

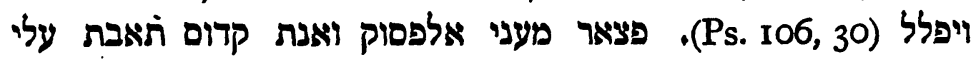

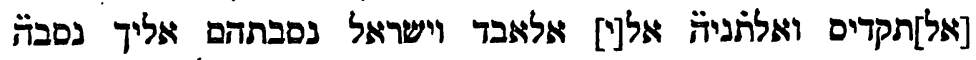

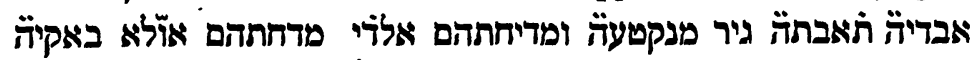

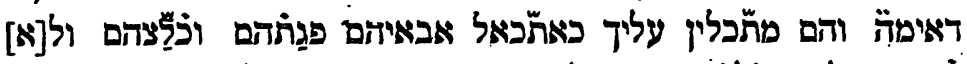

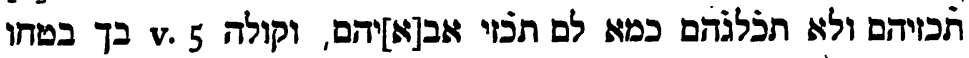

I Vgl. auch Saadia, der diesen Vers, ebenso wie v. 4 in Verbindung bringt mit v. 2. (cf. ed. Lehmann, p. IV).

2 Die folgenden Ausführungen Tanhûm's lassen sich wegen des sehr lückenhaften Textes nicht im Zusammenhang wiedergeben. Der Sinn ist, dass der Mensch sich bedrückt fühlt, trotz seiner Macht zu Gott dennoch durch die sinnlichen Begierden der hohen Stufe entrückt und in den Staub gezogen zu sẹin. Und die Welt der Sinneslust wird mit den im Staube befindlichen Würmern (אלחשר) verglichen. 
Menschen sind ja Gott nahe in ihrer Stufe. v. 2r. Der erste Teil des hier erhaltenen Textes spricht von dem Vers Prov. 14, 4, indes ist mir nicht ganz erklärlich, in welchem Zusammenhang dieser mit dem Psalmvers stehen kann. Vielleicht will Tanhûm, der diesen Vers überhaupt allegorisch erklärt, sagen, dass die Seele, die durch ihren Aufenthalt im Körper leicht der Entwürdigung ausgesetzt ist, nur durch die Thätigkeit des Intellectes nutzbar zu machen ist; sonst werden die Vorräte der seelischen Kräfte nutzlos vergeudet. [In diesem Sinne deuten den Vers Prov. I4, 4 auch allegorisch R'Levi ben Gerschon, genannt Gersonides, in seinem Comm. a. 1., und R'Menahem Meiri aus Perpignan, in seinem Comm., ed. Fürth 1844 . Letzterer weist noch hin auf שלפים Rinder gleich welches in philosophisch-allegorischer Etymologie zusammenzustellen ist mit שור schauen, und so auf das richtige Sehen des Verstandes zu beziehen ist. Vergleiche auch die diesbezügliche שור im Geutung vonsatz zu תמור, gleich חמר ,Sinnlichkeit", in dem von mir herausgegebenen Midr'sche Hathorah von En Salomo Astruc (XIV. Jahrhundert) zu Deut. 25, 2, p. 200. Zur Erklärung von אבוסים als Vor-

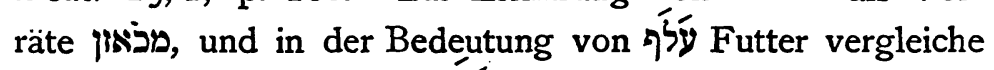

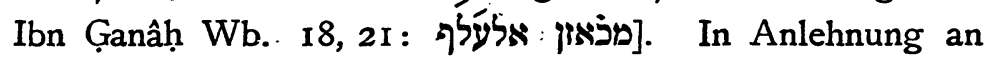
diese Auffassung der Stelle in den Prov. will nun vielleicht Tanhû̉m auch den vorliegenden Psalmvers so deuten als handele es sich um die Rettung der Seele von dem Schwerte, d. h. der Vernichtung durch die Leidenschaften, und vor der hündisch-niedrigen Verunreinigung durch diese. - Das, was in dem Text lesbar ist, sei in folgendem, so weit es der nicht lückenlose Zusammenhang zulässt, wiedergegeben: Die Menschen sollen sich von ihm, - wahrscheinlich ist damit der oben genannte עקל, Verstand gemeint - leiten lassen, von ihm gleichsam Belehrung und gute Sitten einsaugen. 


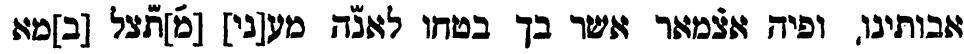

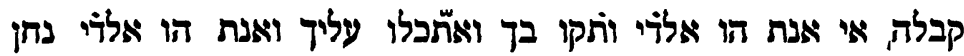

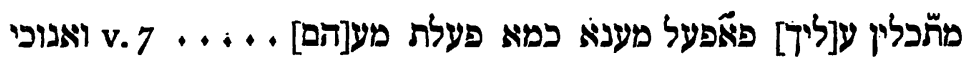

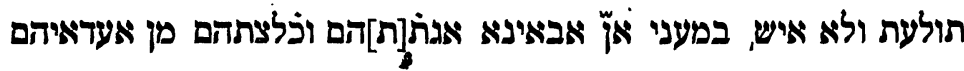

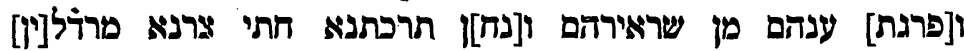

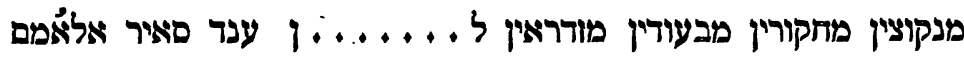

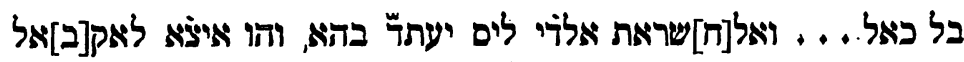

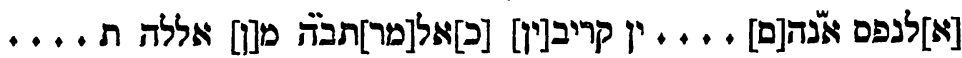

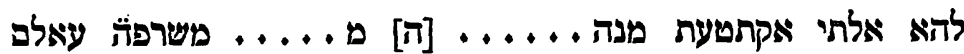
אלתקדים פי מראתבאת אלעאליה ען הלגםמאניה וכתאפתהא ....

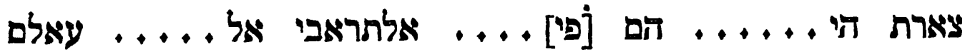

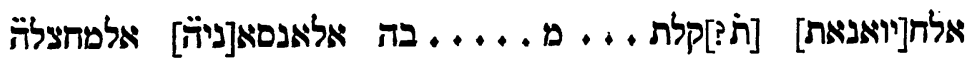

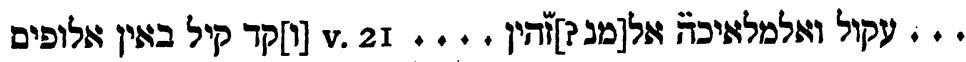

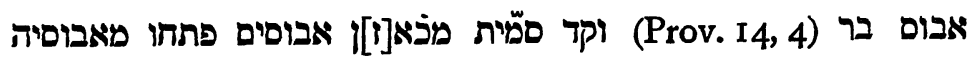

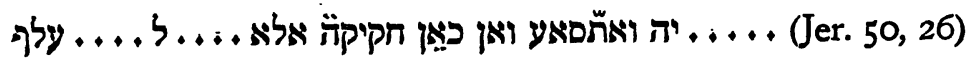

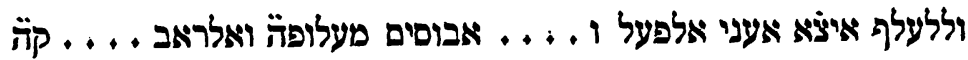

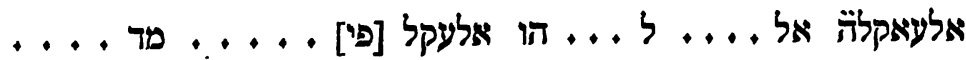

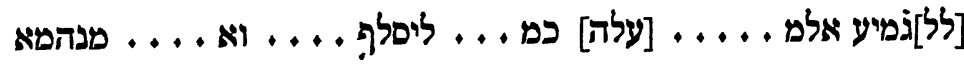

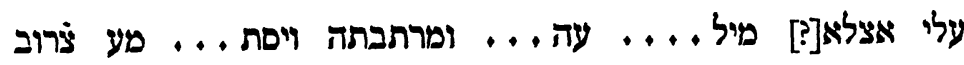

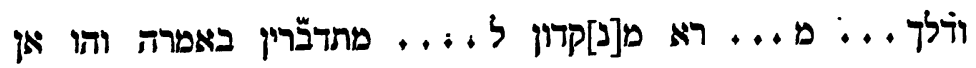

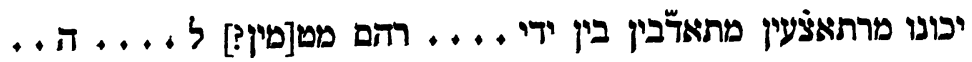

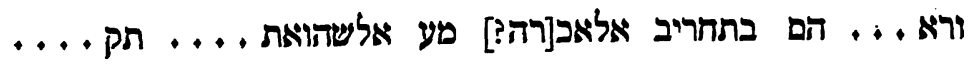

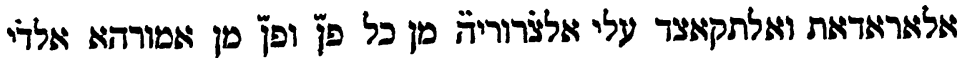

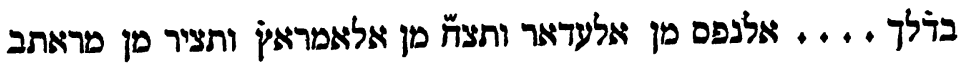

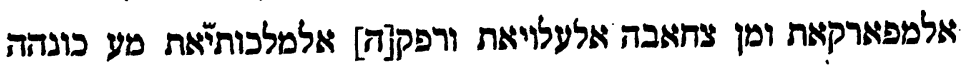


[und dies soll bestehen] in der Bekämpfung des Hässlichen in den Leidenschaften, und der Beschränkung alles Strebens und alles Gelüstens auf das Notwendigste in jeder Hinsicht. Denn nur dadurch kann die Seele von allem Lügenhaften befreit werden, kann sie von ihren Krankheiten gesunden und auch gehören zu denen, die auf den Stufen der separaten Intellecte stehen, und gehören $z u$ ihren erhabenen Genossen und $z u$ ihren geistigen Stützen, indem sie das Vergängliche und Unsichere zum Guten leitet. .... So sah auch David seine Seele gelangen zu einem ähnlichen Grade, und glücklich werden durch die Kraft eines solchen Glückes, und so spricht er mit den Worten von Ps. 103, 2 fgg. o Seele bekenne Gott, preise und rühme ihn, der dir geholfen und beigestanden hat, dich befreit hat von deinen Feinden, dich hat von deinen übrigen Leiden gesunden lassen ... . Darum heisst es dort: preise meine Seele Gott, und vergiss nicht all' das, was Er dir erwiesen hat, wie es sich ergeben wird als Sinn und Bedeutung dieser Stelle, wenn wir mit Hilfe des hilfreichen Gottes dazu kommen werden. Mit den Worten in v. 22: Hilf mir aus dem Rachen des Löwen, sind gemeint die fremden, den Menschen vom Guten abziehenden Kräfte.

\section{Cap. 27.}

v. 4. [Er wünscht sich ein Leben erhaben über] jeder Unsicherheit, frei von der irdischen Unsicherheit, vielmehr nur die Sorge und die Hingabe für die Welt der weihevolleren geistigen Vorstellungen ${ }^{x}$ und deren. Annehmlichkeiten $\mathrm{zu}$ kosten. Dies ist der tiefer liegende Sinn des Verses. Die offen liegende Auffassung ist: das Verweilen im Gotteshause und das Wohnen in Jerusalem und das Vergnügen am beständigen Dienste Gottes daselbst für die Dauer seines Lebens, wie es die Worte מל ימי חי לי besagen. Er erklärt hiermit, dass er ausser diesem keine andere 
מדב̆רה אלמרכביאת אלדי למא רא]י[ דוד ע"ה נפסה קד וצלת למתל

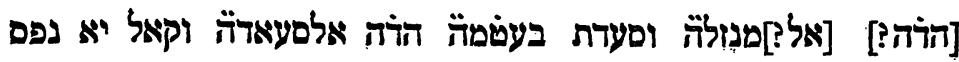

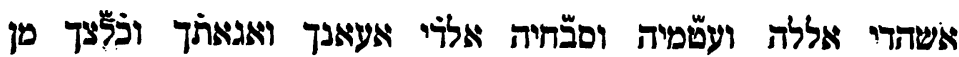

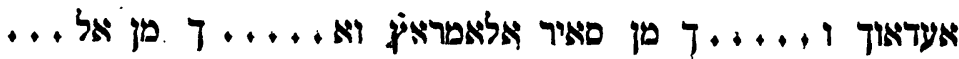

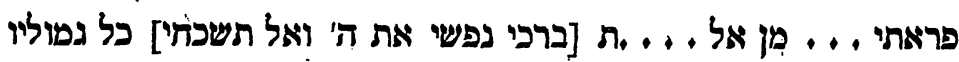
(Ps. IO3, 2)

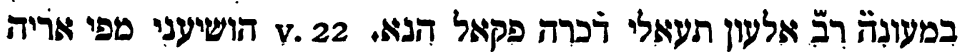
אלקו"ה אלנועיה"ה.

\section{Cap. 27.}



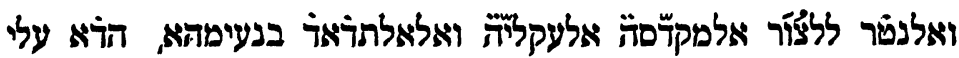

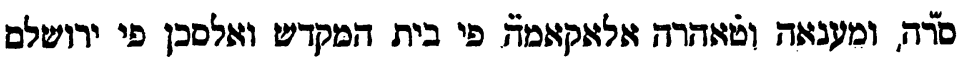

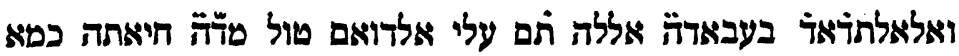

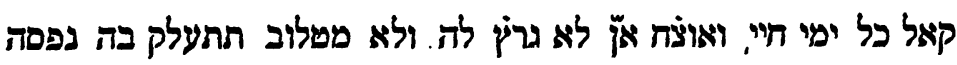

I Vgl. hierüber, wofür Tanhûm, in seiner allegorischen Erklärung von Jona, bei Kokowzoff St. Petersburg 1897, p. 21 des Sep.-Ab-

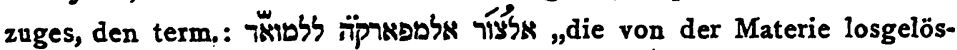
ten Vorstellungen" anwendet, die Ausführungen von Kokowzoff, ibid. p. 150-I5I Anm. 109. Dieselbe allegorische Erklärung der Stelle siehe auch bei David Kimhi a. $i$.

Zeitschrift f. d. alttest. Wiss. Jahrg. 23. II. Ig03. 
Absicht verfolgt und kein Verlangen hat, an dem seine Seele hängt, und worin er nach Gott strebt und ihn sucht, dass dic Dinge dieser Welt für ihn nichts Erstrebens- und Begehrenswertes haben und er sich ihnen nur mit grosser Enthaltung widmet, während er sich edleren und Gott näheren Dingen mit Eifer, Liebe und in Genügsamkeit mit dem Notwendigsten hingiebt. Dies wird auch ausgedrückt in der ersten Vershälfte, die eben besagt: ich erstrebe und verlange nur dies. 'Die Femininformen von אותה setzen die Ergänzung eines Wortes, wie שאלה oder, בקשה oder dergleichen voraus, was dem Sinne angemessen ist. ולבקר bedeutet: beständig am Morgen da sein, von בוקר Morgen abgeleitet ${ }^{x}$. Der Sinn ist: beständig, beharrlich sich dort aufhalten, wie in Exod. 30, 7, ständig an jedem Tage und an jedem Morgen. v. 6 . Über meine Feinde, die mich zornschnaubend umgeben, und von denen es in v. 3 heisst: wenn auch sie mich umlagern. $\mathrm{Zu}$ ergänzen ist dabei אשר oder בעת, zur Zeit. ${ }^{2}$, d. h. höre meine Stimme und nimm mein Rufen an, wann ich dich anrufe, $z u$ dir hinstrebe und von dir etwas zu erlangen suche. v. 8. Th hat den Sinn von ענך, "deinetwegen“ wie in Gen. 20, 13, Jud. 9, 54 3; eigentlich sollte es heissen: von dir spricht mein Herz zu mir, im Sinne von 'isצ', es rät mir dazu 4, und führt mich dahin und weist mich darauf hin. Für פy sollte es eigentlich heissen פניו, da es sich ja auf Gott bezieht, zu dem er auch in den Worten לך לך spricht. Er will also etwa sagen: Mein Herz und mein Verstand weisen auf nichts Anderes mich hin, als Gott zu suchen, und lassen mich in Niemand Anderem meine Stütze suchen. Dann fährt der Dichter fort mit den Worten: Dein Angesicht o Ewiger suche ich, d. h. er will annehmen und in Gehorsam das beobachten, worauf ihn Herz und Verstand hinweisen, und wovon in den 


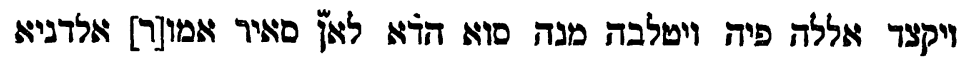

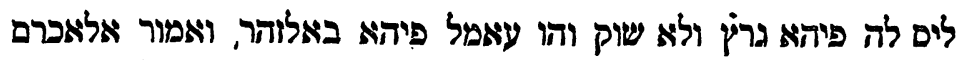

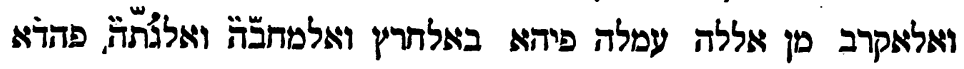

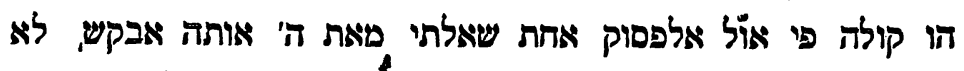

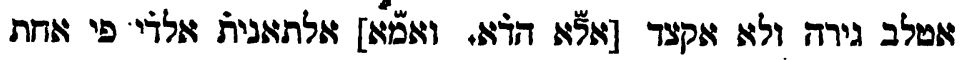

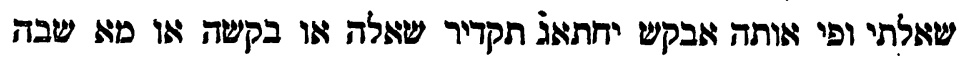

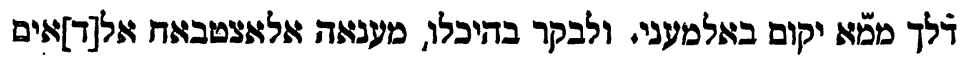

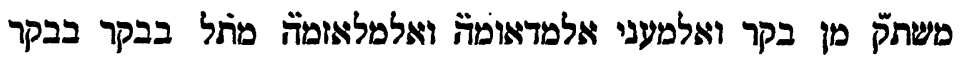

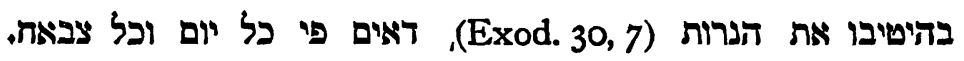

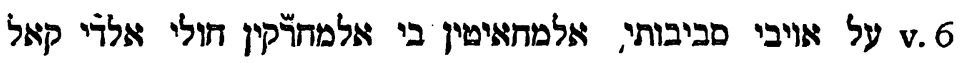

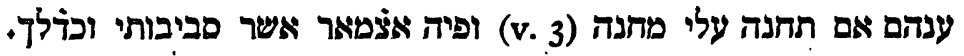

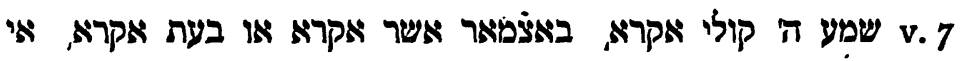

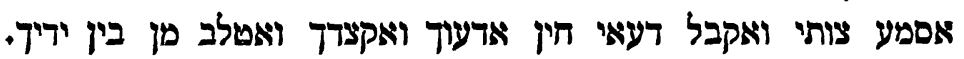

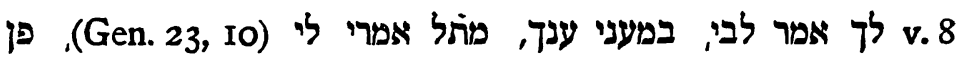

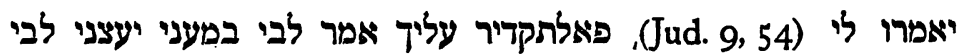

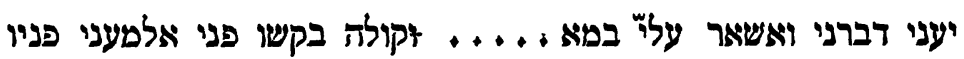

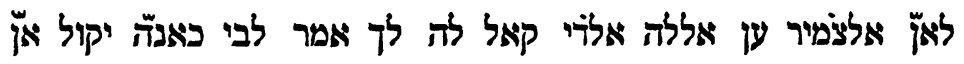

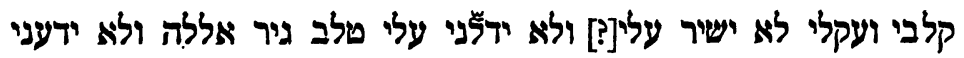

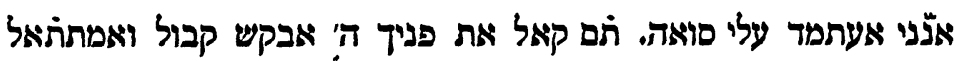

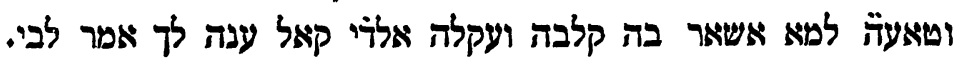

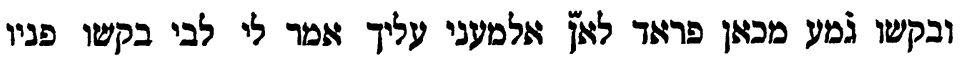

I Dieselbe Erklärung findet sich auch bei Ibn Gạâh Wb. 106, 6, wozu noch, nach Note $5 \mathrm{I}$ ibid., eine Randglosse der Ms. Oxford jedenfalls aus Juda Ibn Bal'âms Buch ủber die verba denominativa bemerkt מאכוֹ מן בקר.

2 So hat auch Saadia a. 1. (ed. Lehmann p. VIII) הזרא דעות.

3 Auch Saadia (ibid.) hat עy. Vgl. auch David Kimhi a. 1. Das $\Rightarrow$ in Gen. 23, I0 übersetzt Saadia a. 1. (ed. Der. p.19) auch mit עי עי 4 Vgl. auch Dav. Kimhii יסרי 


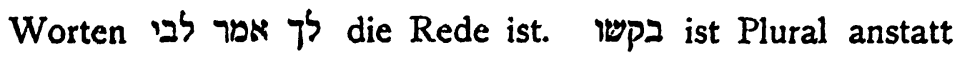
des Singulars, der eigentlich dem Sinne nach erforderlich ist: Der Dichter sagt nun, dass er dieses beobachten und darnach streben werde. "Ich suche Dich Ewiger", und so mögest $\mathrm{Du}$ auch Deine Fürsorge für mich nicht verdecken und Dein Licht nicht vor mir verbergen. Möglich auch, dass mit den Worten בקשו פני der Dichter den Intellect selbst sprechen lässt, da er eigentlich die Ursache der Erkenntniss Gottes ist und den Menschen veranlasst, sich an Gott zu wenden. Die Worte $ם \pi$ s etc. sollen nach Einigen so lauten האל תמה הפך לעברך, Neige Deinen Zorn nicht zu Deinem Diener," d. h. beuge ihn nicht und lasse ihn nicht etwas thun, das wohl ihm selbst gefallen mag, jedoch ihn in Deinen Zorn fallen lässt und Deinen Unwillen über ihn hervorruft. $\Delta ת$ ist ein transitives Hiphil, mit apocopiertem ersten und letzten Radical, wie $T^{\prime}$ in Exod. 8, 25, $M$ Lev. 8, I u. a. m. Die vollständigen Formen lauten, ויינוה, וינכה, mit Aufgehen des Nùn תמטה ir. Auch das Pathach des ersten Radicals im Futur beweist, dass es eine Hiphilform ist. Nach Einigen wäre hinter ט zu ergänzen משפטך und ähnliches, so, dass zu übersetzen wäre: Neige oder beuge Deine Hand, oder Deinen Zorn oder Deine Führung nicht im Zorn gegen Deinen Diener, so dass das Transitive durch die Objecte

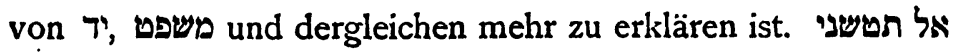
bedeutet: verlass mich nichit und trenne $D i c h$ nicht von mir, ganz so wie תעובני, ebenso wie in Prov. I, 8.

v. I I. "שוריר zeigt eine Verdoppelung des dritten Radicals

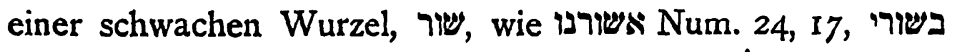
Ps. 92, 12. Die Verdoppelung ist wie in לוצ' Hosea 7, 5, von $\gamma^{\prime}$, wie in Prov. 14, 9. Der Sinn ist: die auf ihn mit feindlichen, lauernden Blicken sehen, wie ${ }^{\mu}$ in I Sam. 18, 9, das von Auge abgeleitet ist ${ }^{x}$. Da ' 


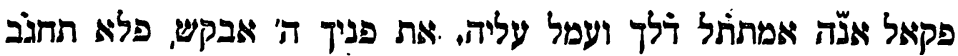

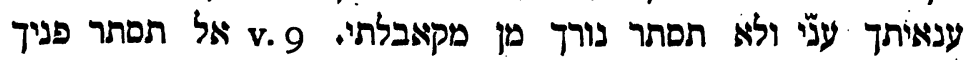

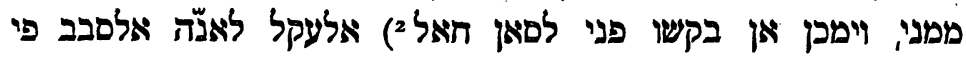

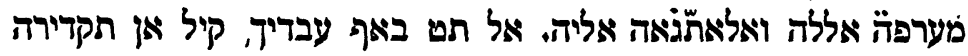

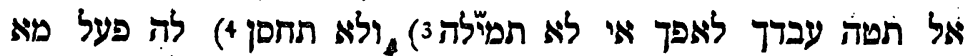

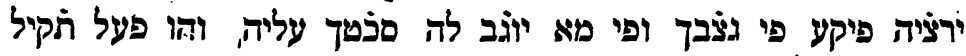

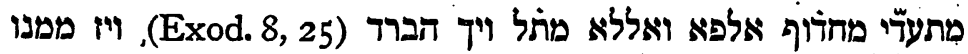
(Lev. 8,.I)

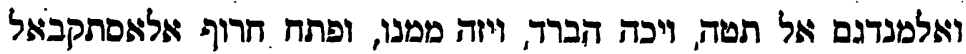

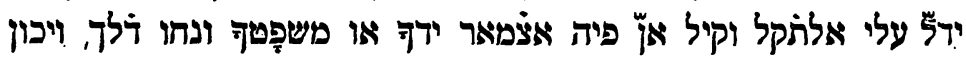

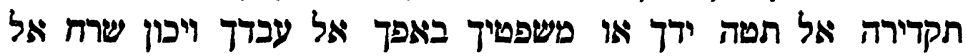

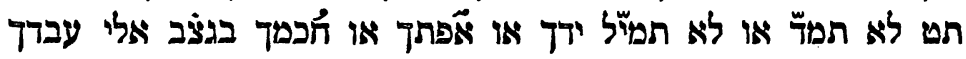

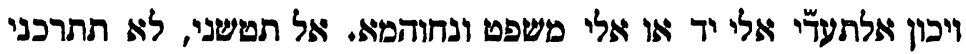

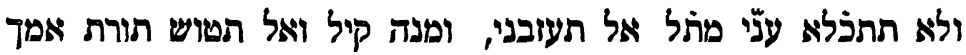

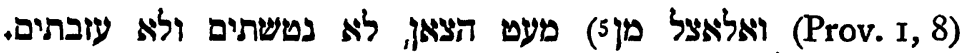

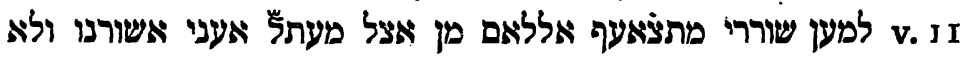

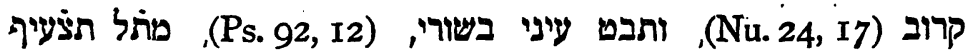

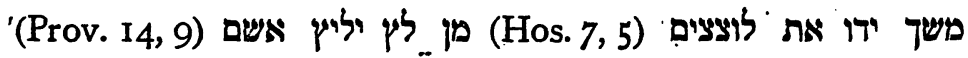

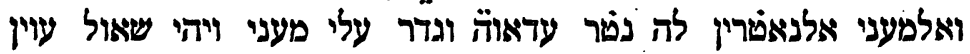

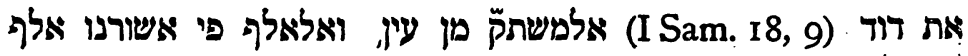

I Diese Ausführungen Tanhûm's, die sich auch mit seinen Bemerkungen I Sam. 18, 9 (ed. Haarbr. p. 32) berühren, beruhen auf Ibn Gạ. Wb. $711,21-22$.

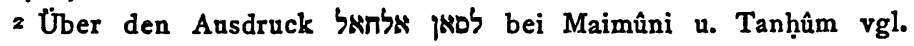
Munk, Commentaire de R' Tanhoum sur Habakouk, Par. 1843 p. 94 No. 2.

3 Ganz so Saadia a. 1. (ed. Lehmann p. VIII). Doch weiss ich nicht, warum dieser ibid. p. 29, es mit "wanken lassen“ wiedergiebt.

4 Schwer verständlich ist hier dieses Wort. In der deutschen Wiedergabe folgte ich dem Vorschlage des Herrn Dr. Poznański.

5 Hier muss nach dem Vorschlage des H. Dr. Poznański wohl folgendes ergänzt werden: לוואר אלנו"ן ואלנו"ן מנדגם באלטמית (I Sam. 17, 28)

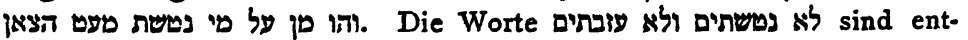
weder ein ungenaues Citat oder Corruptel des Copisten von Jer. 12, 7. 
Num. 24, 17 ist das ' $\wedge$ der ersten Person im Futurum, wie

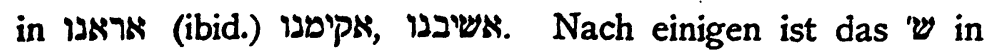
שוררי an Stelle des 3 ', indes bedarf es dieser Annahme nicht, da die Ableitung und Bedeutung des Wortes auch ohnedies klar sind. v. 12. האל תתנני bedeutet: liefere mich nicht ihrer Leidenschaft und ihrem Willen aus. So ist auch נפשו in Ps. 105, 22 aufzufassen: nach Maassgabe seines Willens, נפשכם in Gen. 23, 8: wenn dies euer Wille dies, und עפש Jes. 56, II, stark an Begierde?. Der erste Radical, das Nûn, ist bei

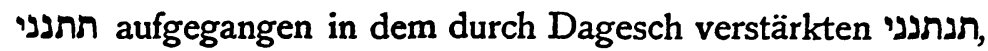

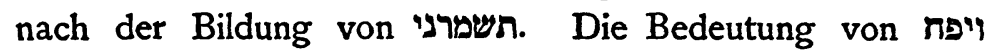
ist: deren Mund Unrecht und Gewaltthat von sich giebt, d.h. die beständig davon sprechen und sich damit beschäftigen, wiẹ ויפיח in Prov. 6, 19 ,der beständig von Lüge spricht“. Allerdings sind es zwei verschiedene Wurzeln, indem יפח hier zu einem Verbum mit schwachem ersten Radical gehört, der hier ein Jod ist, wovon die schwere Form תתיפח Jer. 4, 3I lautet, während יפיח Prov. 6, I9 von einem Verbum med. Jod ist, wobei das Jod das Futur bezeichnet, wie in

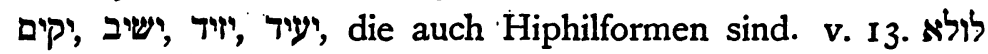
etc. ist eigentlich ein Vordersatz, dessen Nachsatz fehlt, als welcher $z u$ ergänzen wäre etwa „dann wäre ich in meinem Elende untergegangen, oder vertrieben oder weggerafft worden" und drgl. mehr ${ }^{3}$, damit der Sinn und die Absicht des Satzes vollständig erreicht sind.

\section{Cap. 28.}

v. I. Zu Dir, Ewiger, rufe ich, d.h. ich rufe keinen anderen ausser Dir an. Das Wort אל תחרש,schweige nicht" ist hier in übertragenem Sinne aufzufassen; es bedeutet das Lässigsein und Schweigen ohne zu antworten, abgeleitet von חרש, d. i. der durch Taubstummheit am Sprechen behindert ist. Der Sinn ist: stelle dich nicht taub und sei nicht lässig in der Annahme meines Gebetes und meines 
אלמתכלّם ללאסתקבהל מתל אל"ך אראנו, אקימנו, אשיבנו, וקיל אה"

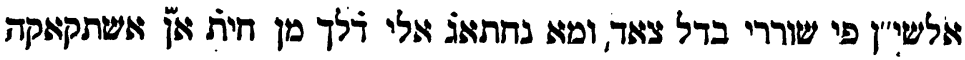

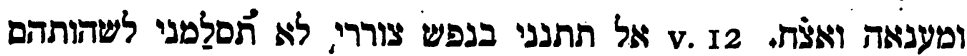
ואראדתהם, ומתלת לאסור שריו בנפשו (Ps. 105, 22) בראיה וחסב

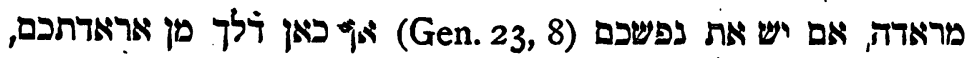

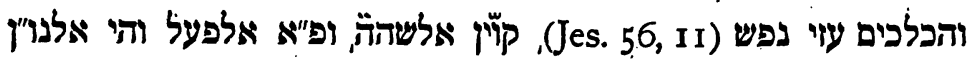

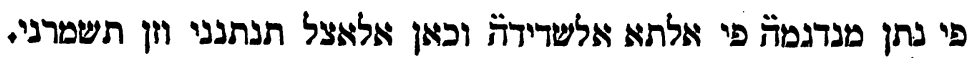

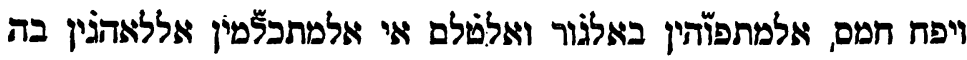

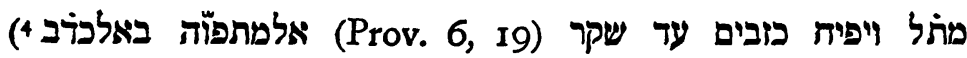

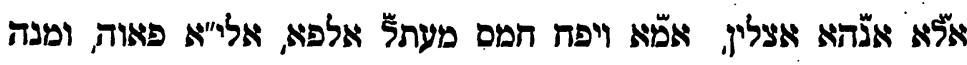

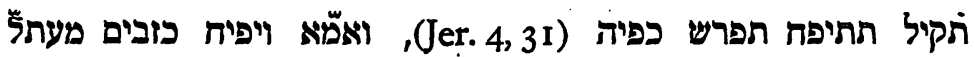

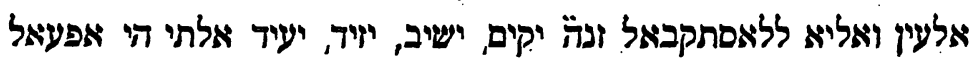

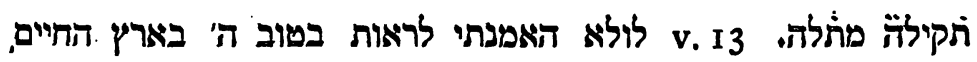

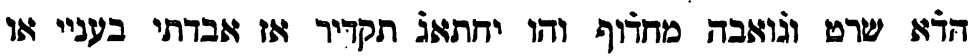
גורשתי או נגורתי או מא שבה זלך ליתם אלמעני ויכמל אלגריץ.

..Cap. 28.

v. I

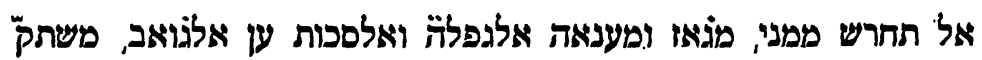

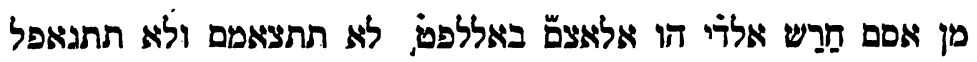

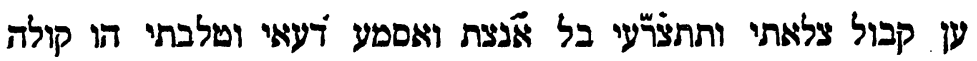

I Vielleicht ist hiermit Saadia gemeint, der nach einem Ms. d.

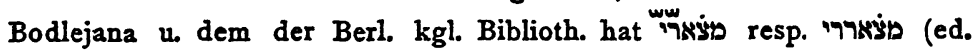
Lehmann p. VIII Note 16, Ewald u. Dukes, Beitr. I p. 27), während eine

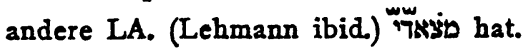

2 Ganz so lauten auch die Ausführungen von David Kimḥi, der gleichfalls Gen. 23, 8 anführt, hier u. Ps. 105, 22 u. Jes. 56, 11. Auch

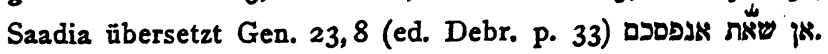

3 Vgl. hierzu auch die Bemerkungen bei Dav. Kimhi a. 1.

4 Dasselbe hat auch. Saadia hier (l. c.) u. Prov. 6, 19. 
demütigen Flehens, sondern merk' und höre auf mein Rufen und Hilfesuchen. So drückt es auch der folgende Vers aus: Wenn ich dich um Hilfe anflehe und mich in Bitten vor dir demütige, höre auf meine Stimme und nimm mein Flehen an. דביר bedeutet nach Einigen den Ort des Allerheiligsten ${ }^{x}$, nach anderen den Vorraum wie היכל in Ps. 5, 8². Der Sinn ist auch so verständlich, trotz der verschiedenen Ausdrücke. v. 3. Vereinige mich nicht mit den Übelthätern und lass mich an ihrer Gemeinschaft nicht teilnehmen. Die eigentliche Bedeutung des Wortes ist das Ziehen und lange Anhalten; dann ist es übertragen auf das Langanhalten der Stimme in einem gewundenen Instrument oder das Ziehen aus dem Horn, wie במשוך היובל Exod. 1933, 13, wo es eigentlich heissen müsste במקר היובל, wie es auch thatsächlich so heisst in Jos. 6, 5. Dann ist aber auch sowohl יובר, wals auch wer der Widder gemeint ist, ausgelassen, wie bei משכת Jud. 4, 64, welches den Sinn hat: „versammle"; wenn auch eigentlich nach dem Wortlaut gemeint ist das Stossen in die Posaune, damit sich alle, die es hören, um ihn sammeln, so ist aber doch mit der Wendung beabsichtigt: geh', rufe die Männer zusammen und vereinige sie zum Kampfe. Dann ist das Wort auch übertragen auf jede durch Übereinstimmung veranlasste Ansammlung zwischen Menschen und auf deren Vereinigung $\mathbf{z u}$ irgend .einem Zwecke, wie משכו in Exod. 12, 21, wo der Sinn ist: sammelt euch zu. Vereinigungen, beteiligt euch und tauschet nach Maassgabe des Bedarfes einer jeden Gesellschaft, wie es ihre Zahl erfordert; so geht es auch aus v. 5 dort hervor. Daher hat auch sie Bedeutung von תאל תאפי: vereinige mich nicht mit den Frevlern, wie in Ps. 26, 9, was wir bereits auseinandergesetzt haben. Einige meinen dass משכת in Jud. 4, 6. die Bedeutung von "sich ausbreiten" hat, als wenn es 


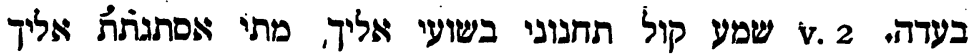

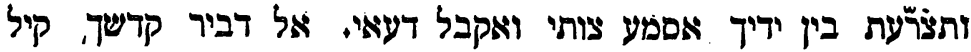

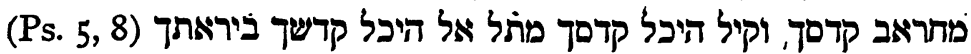

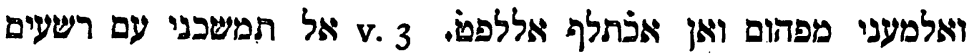

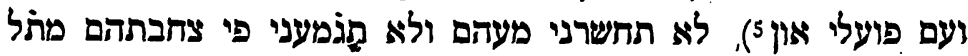

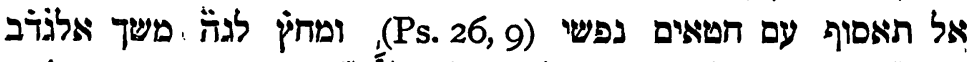

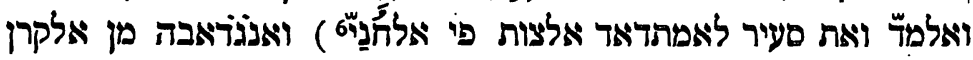

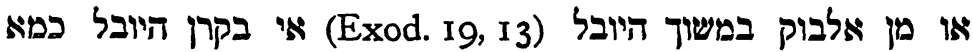

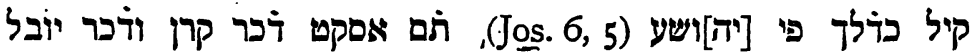

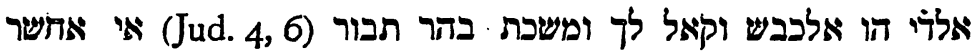

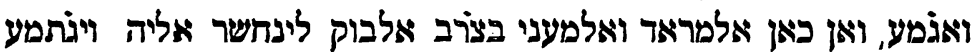

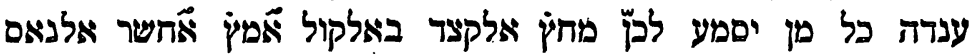

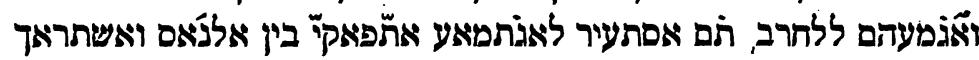

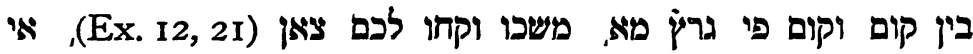

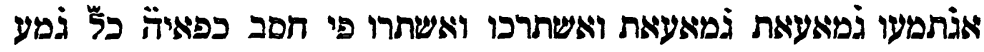

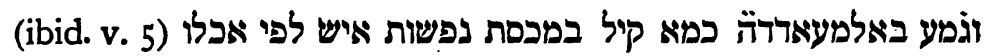

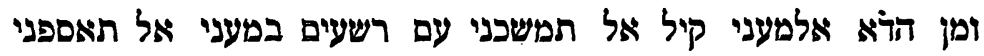

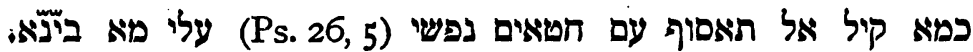
וֹסם מן קאל און מעני לך ומשכת בהר תבור אלאנבסאט כאל ...

I Auch Saadia giebt es hier mit מתראב wieder (ed. Lehmann p. IX); vgl. auch Lehmann p. 31 Anm. I. Cf. auch Abr. ibn Esra u. David Kimḥi a. l.

2 Dort wendet auch Sa.adia dies Wort an (ed. Margulies p. 5).

3 Saadia a. 1. (ed. Derebg. p. 109) hat auch בצוֹ הלבוק. Auch I. G.. Wb. 395,17 bemerkt מתל בתקוע.

4 Dav. Kimhi a. 1. fasst מש מש auf im Sinne von ,an sich ziehen“ durch Überredung, wie es im Neuhebr. des Talmud u. der Midraschim oft gebraucht wird.

5 Diese Stelle bis ללחרב veröffentlicht Poznański ZHB 1. c. p. 126 mit Hinweis auf Tanhûm's Comm. zu Josua 6, 5, ed. Haarbrücker p. 9-10. - Saadia übersetzt hier (ed. Lehmann p. IX) תגנרבני, wol weil חש auch den Sinn von "wegraffen" haben würde, wie es auch aus seinem Comm. ibid. p. IX $-\mathrm{X}$, hervorgeht.

6 Meines Erachtens kann sehr wohl diese LA. beibehalten werden, 
hiesse ', wie auch ועשמטתם Hiob I, I7 gebraucht ist, I Sam 27, 10, wo kleich is ist durch Permutation der Dentalia. Indes entspricht es mehr dem Sinne und Bedeutung der Stelle, משכת im Sinne von "Sammeln" aufzufassen, da dort von einem Raubzuge nicht die Rede sein kann, denn der Zusammenhang erfordert eine Sammlung der Menschen zum Kampfe und nicht einen Plünderungszug. v. 5. Sie betrachten und beachten nicht, was der Verstand von ihnen fordert, und das wachsame Erkennen und die Aufmerksamkeit, welche die Lässigkeit abstreift, so dass sie durch ihre Vernachlässigung dessen in ihrer Unwissenheit bleiben, versunken in ihrer Blindheit, einhertreibend im Meere ihrer Unwissenheit, sich selbst verwundend im Blut ihrer Niedrigkeit, wie es in Jes. 5, I2 ausgedrückt ist: sie schauen nicht auf Gottes Thaten und sehen nicht das Werk seiner Hände; hierauf heisst es in v. 13: Darum muss mein Volk durch seine Unwissenheit in die Verbannung gehen, und als Endfolge wird in v. I4 angegeben: dadurch ist für sie das Verderben breit geöffnet. Mit יביטו ist dort gemeint das sich Hinwenden und genaue Betrachten, wie in Gen. 19, $17^{2}$ und 2 hier hat dieselbe Bedeutug wie ואתבונן I Reg. 3, 2I, בינות Dan. 9, 2, Prov. 23, 9 ibid. 7, 7 wo dasselbe bedeutet wie ואבינה ,betrachten", wie auch in Jes. 5, 12 יביטו Wenn aber es hier. bedeuten sollte erkennen und verstehen ${ }^{3}$, so müsste statt nicht mit der Erkenntnis beschäftigt und nicht beachtet wodurch er erweckt werden kann aus der Trägheit, so dass sich ihm daraus ein Untersuchen, Nachdenken und Betrachten ergiebt, der gleicht einem Toten, wenn er auch lebt, fühlt und sich bewegt, da er nichts bemerkt, nichts weiss und sich von nichts' eine Vorstellung macht, so dass er ganz aufhört und sein geistiger Bestand aufgelöst wird, von ihm 
כאביה קאל לך ופשמת כמא קיל ויפשטו על הגמלים ויקחום (Hiob I, I7)).

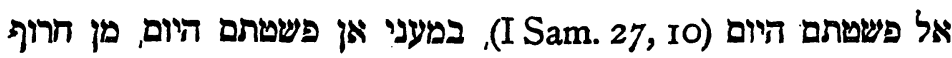

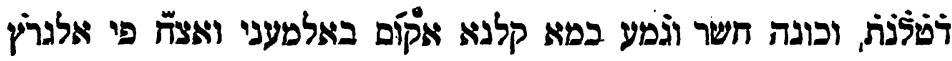

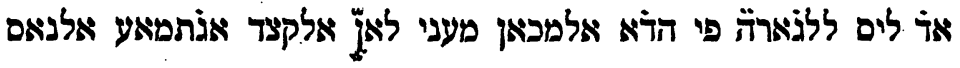

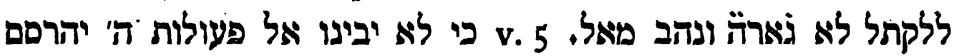

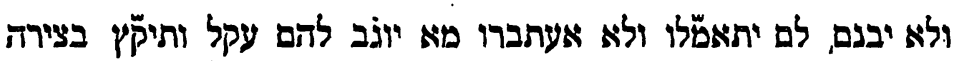

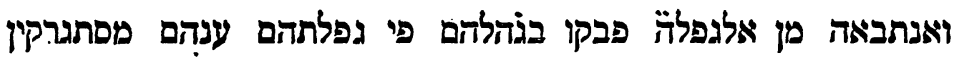

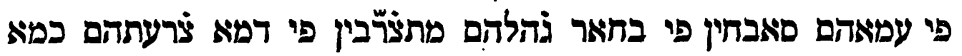

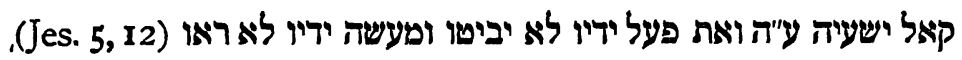

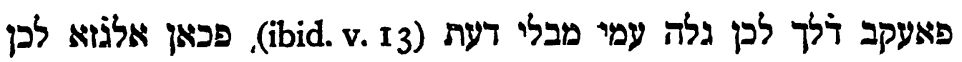

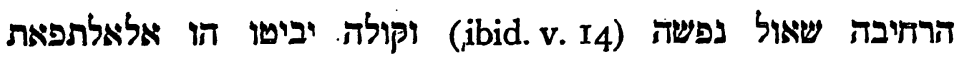

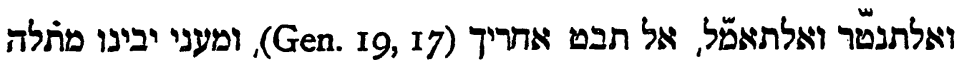

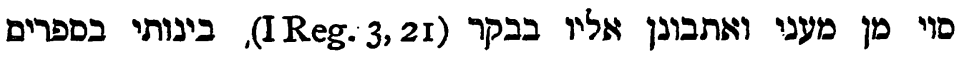

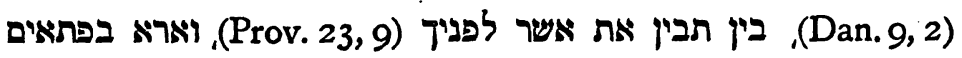

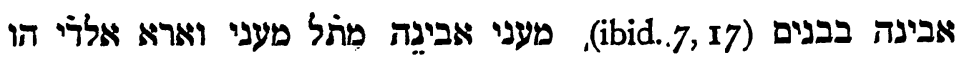

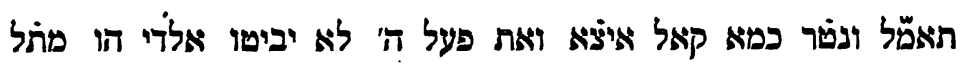

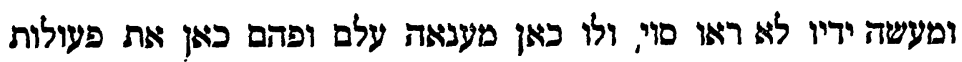

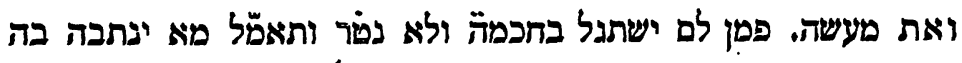

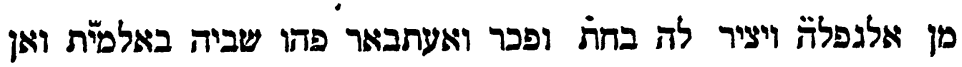

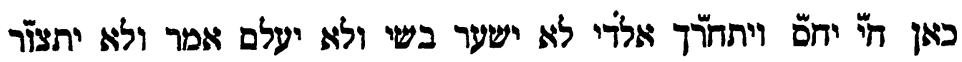

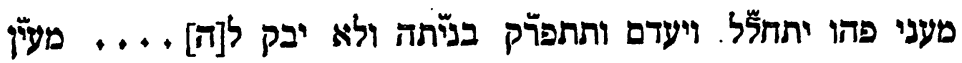

ohne sie, mit Goldziher ZHB 1. c. p. 185 in $j$ ל, das hier, meines Er. achtens, keinen Sinn giebt, zu emendieren.

I Damit ist gemeint Ibn Ganâh; rgl. Wb. 395, 9 fgg.

2 Sazdia a. 1. hat auch: לא ל אלת (ed. Derenb. p. 28).

3 Hiermit steht Tanhûm im Gegensatz zu Saadia, der es hier (ed. Lehmann p. 9) durch das von T. beanstandete פה wiedergiebt. 
keinerlei bestimmte Spur bleibt und kein Teil, der auf ihn hinweist, wie es in den Worten יהרםם etc. ausgedruickt ist. v. 6. Alsdann dankt er Gott, der sein Rufen und Streben nach ihm angenommen und ihn nicht der Schar derer zugesellt hat, die mit ihrer gänzlichen Auflösung und Nichtigkeit gekennzeichnet sind. v. 7. Gott ist meine Stärke, Schild und Schutz. Beide, מע und מגנ gehören zu den verbis geminatis, daher haben sie auch ein Dagesch, um das Aufgehen des einen der doppelten Radicale zu bezeichnen, wie wir es wiederholt erläutert haben. $1 y$ ist wie die vollständig erhaItenen Formen $m$ y. Ps. 24, 8, עו (ibid. 78, 5) מעוו Gen. I5, I, das eigentlich מגנון, lauten sollte. Der infinitiv ist 3I, 5. Das praeteritum גנותיibid. 37, 35 und 38, 6. II Reg. 19, 34 ähnlich wie סבותי Koh. 2, 28, חנותי Exod. 33, 19, die

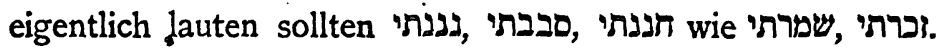

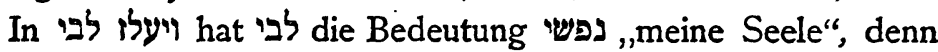
für diese ergiebt sich die Freude dadurch, dass ihre Kraft und Macht in Gott ist, dass Er es ist, der ihm Stärke verleiht und für sie sorgt, da Er ihr Schild und Schutz ist und der Anschluss an Ihn ihr Lohn ist, wie es in Gen. I5, I Abraham verheissen worden ist: ich bin dein Schild, dein Lohn wird sehr gross sein. iy hat mehrere Bedeutungen; zunächst die der Freude und der Heiterkeit, wie hier. In dieser Bedeutung kommt es auch mit y vor, wie pלy I Sam. 2, I, auch mit 'o wie Prov. 7, 8, Hiob 39, I3. Dann hat es aber auch eine der Freude entgegengesetzte Bedeutung, nämlich ,hin- und hergeworfen werden“, auch das Erschlaffen, bei der Nähe des Todes wie mby Jer. 5I, 39, indem es analog dem Arab. ist', wo wל אל bedeutet das Zittern und das sich Hin- und herwerfen, das den Kranken beim Nahen des Todés ergreift, infolge des Sinkens der Kraft und des Schwindens der Körperwärme. So ist. auch das 
ולא גו משאר הליה הו קולד יהרםם ולא יבנם. v.6 ברוך ה' כי

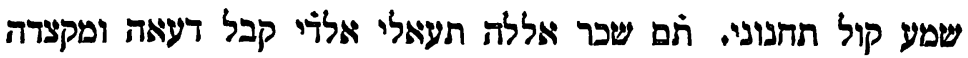

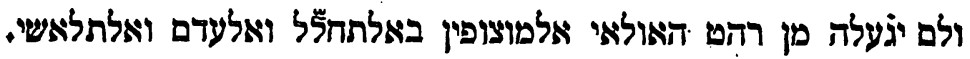

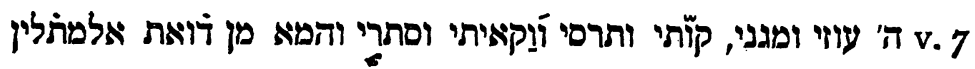

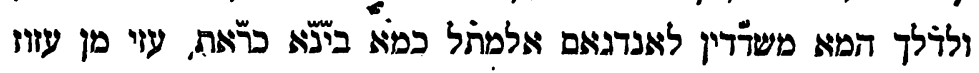

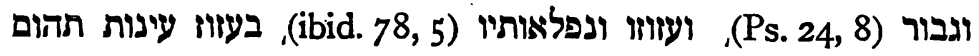

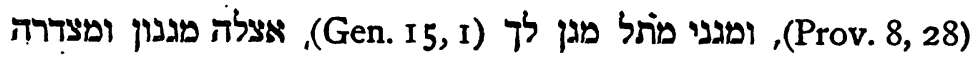

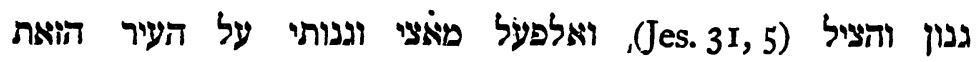
(Koh. 2, 28) (ibid. 37, 35; 38, 36. II Reg. 19, 34)

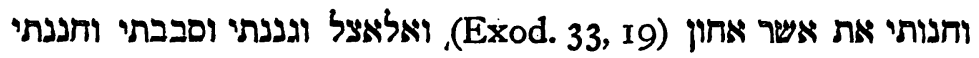

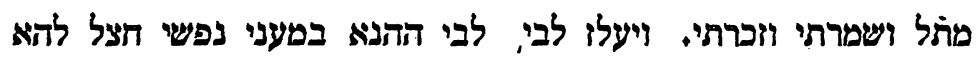

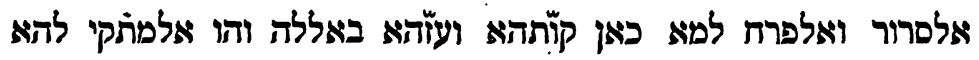

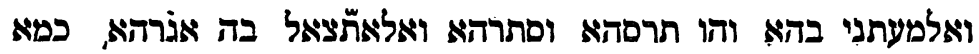

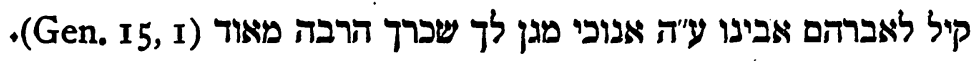

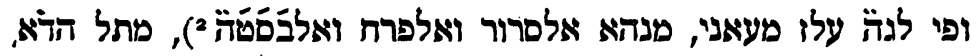

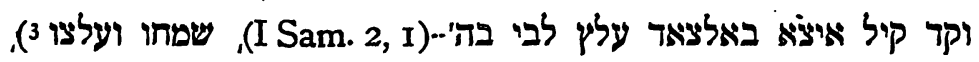

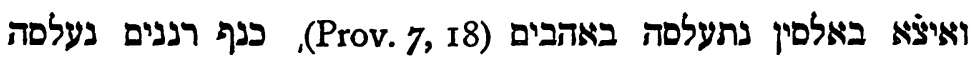

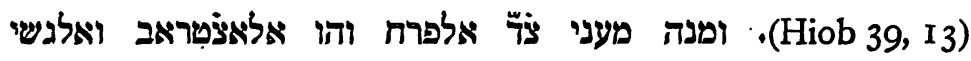

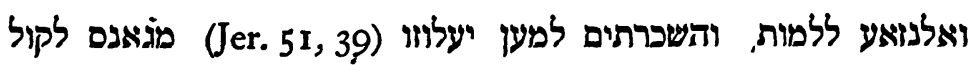

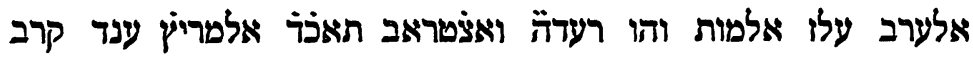

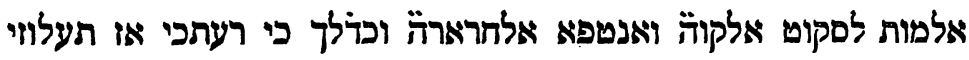
(ibid. II, I5)

I Die Vergleichung, so wie die ganze Erklärung der Stelle sind IC̣. Wb. 528, 9 fgg. entlehnt.

2 Ich kann nicht Poznański ZHB l. c. p. 126 beistimmen, dies Wort in $2 u$ emendieren, auch nicht trotz seiner Bemerkung ibid. p. 185, $\mathrm{d}_{2}$ hier nun von der heiteren Seelenfreude die Rede ist.

3 Ich kann einen solchen Vers nicht belegen. Nach Meinung des Herrn Rabb. Dr. Brody-Nachod ist vielleicht gemeint der Vers 
Wort "Iל in Jer. II, I5 aufzufassen, d. h. wegen deiner früheren Schlechtigkeit droht dir der Untergang, so dass is zusammenhängt mit בי רעתכ, als wenn es hiesse: wegen der Schlechtigkeit, die du früher begangen hast, wirst du untergehen. Dann hatiby noch eine andere diesem entgegengesetzte Bedeutung, nämlich „kräftig und stolż sein" wie in Jes. $24,8$. Zeph. 2, $15^{z}$ "die starke, herausfordernde".

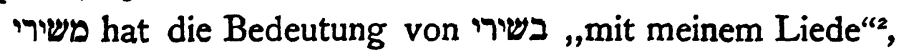
d. h. ich will ihm danken, ihn preisen und rühmen mit meinen Liedern und Gesängen. אהודנו hat hier die

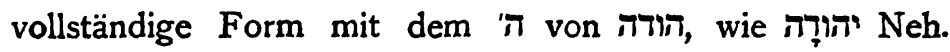
II, 7, יהודוך, Ps. 45, 18. Nach der sonst üblichen Regel sollte das $\pi$ wegfallen wie אודה Gen. 29, 35, יודו Ps. 99, 3, יודוך ibid. 145, I0, מודים I Chron. 29, 13, indem das ' 1 als erster Radical eine Umwandlung des " ist und der dritte

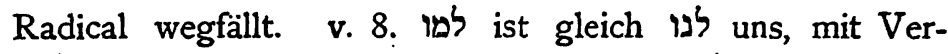
tauschung des ' 2 für ' $מ$, ebenso ist es mit למו in Ps. 44, 10, und so giebt es noch mehrere solche Fälle, wo bei den Suffixen diese beiden Buchstaben mit einander tauschen. Denn es ist ja nicht anzunehmen, dass es sich beziehen soll auf die vorher in v. 5. genannten, vielmehr kann es sich nur beziehen auf die, die von sich selbst hier sprechen, die für ihre Seelen sorgen, und darnach streben, dass Gott ihre Macht und Stärke ist, ihre Únterstützung und ihr Beistand, indem er auf sie merkt, und sich ihrer erbarmt, indem er ihnen einen König giebt, der sie mit Gottes Hilfe führt, wie es in v. 9 ausgedrückt ist, wo רעם und beide die Bedeutung des Führens und Lenkens haben, wie שוע Ps. 23, I und ישהו in Num. II, I23.

Cap. 29.

v. I.4 Unter בני הלים ist die Welt der Sphären und der Sterne zu verstéhen, da mit אלים selbst die Engel gemeint sind, die auch אלהים genannt werden in Ansehung dessen, 


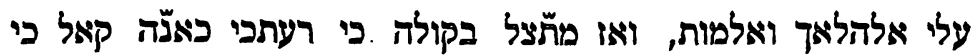

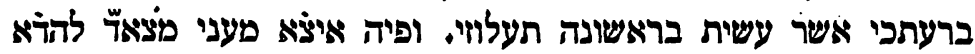

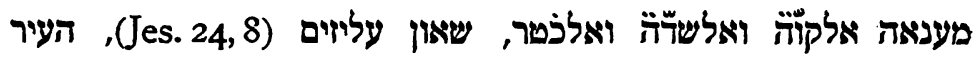

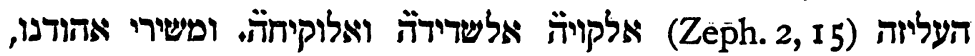

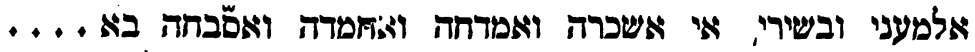

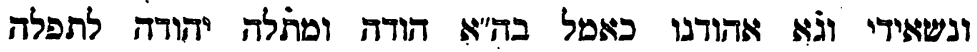
(Neh. II, 7)

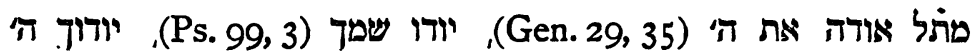
[i] (ibid. I45, I0)

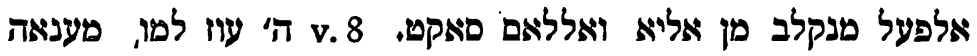

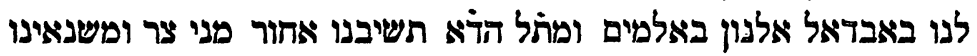

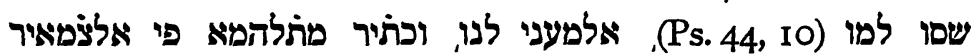

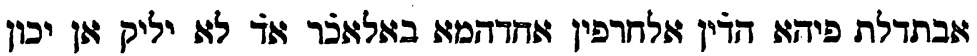

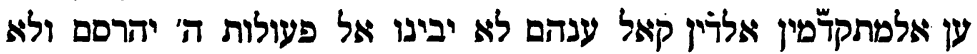

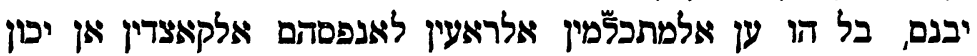

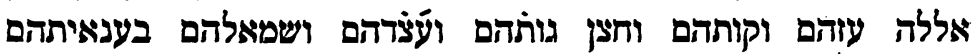

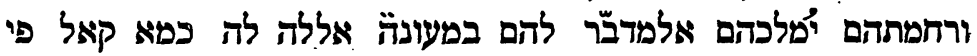

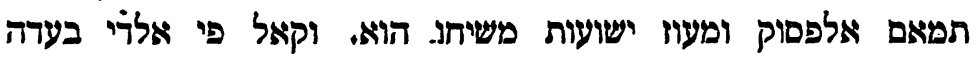

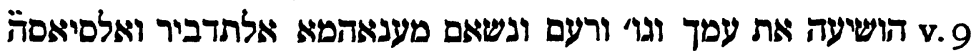

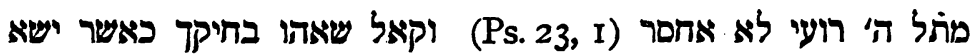
האומן (Num. II, I2)

\section{Cap. 29.}

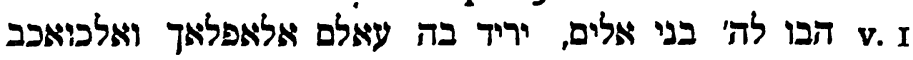

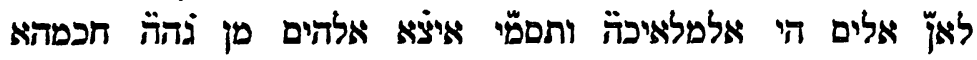

I Auch dort will IG. עליוה in demselben Sinn, wie in Jer. I1, I5 u. 51, 39 auffassen, wegen des folgenden חליך. In Jes. 24, 8 übersetzt Sazdia (ed. Der. p. 34) mit 7 (ע, einer Art Spielinstrument, hingegen עליוה 22, 2 (ib. p. 30) mit פולה "gross".

2 Vgl. auch David Kimhi.

3 An letzterer Stelle wendet auch Saadia (ed. Derbg. p. 208)

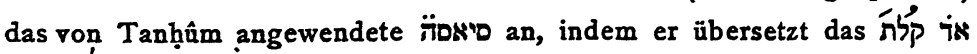

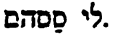

4 Vgl. 2u diesen Ausführungen, wie auch zur Erklärung von 
dass sie das, was unter ihnen ist, beherrschen und leiten, wie auch Gott in Deut. 10, 17 אלהי אלהים ואדוני האדונים genannt wird „der Führer aller Führer", da er der oberste Führer ist, der alles, was ausser ihm ist, lenkt, und das erste derselben sind die Intelligenzen, welche der Dichter mit Engeln bezeichnet, und unter ihnen ist der Rang der Sphären und der Sterne, und diese werden בני אלים genannt. Er erwähnt sie aber zuerst, da die Thätigkeit der Engel, der Intelligenzen und Wesen, wie auch ihr Erfassen, welches in ihrem Preis und ihrer Verherrlichung Gottes besteht, uns verborgen und unzugänglich ist für das Erfassen mit unserem Verstande, da wir uns in der niederen Welt befinden. Wir können jedoch einen Schluss auf das wenige, was uns davon klar ist, ziehen mit Hilfe der Welt der Sphären, da diese uns näher ist und ihr Erfassen dem unsrigen näher ist, auch unserem Vorstellungsvermögen näher steht als das Erfassen der separaten Intelligenzen. Diese Welt aber ist ohne Zweifel höher als die Welt der Elemente und darum ist sie ihr, infolge ihrer grösseren Erhabenheit, vorangestellt. Er erwähnt aber die Engel später, weil ihr Erfassen am Anfang schwer ist. Und so hat es auch Ezechiel bei der Schilderung der Merkaba gethan, indem er zuerst die Hajôt, dann die Ofanîm, die unter ihnen sind, und dann nach allem den Haschmal, und was mit ihm zusammenhängt, erwähnt hat, obwohl dieses im Range den übrigen Welten vorangeht ${ }^{x}$. הבו ist eine andere Ausdrucksweise für נתן geben, deren sich auch das Targûm bedient; es hat hier den Sinn wie תנו לה' כבוד Jer. 13, I6. Es wird sowohl in der Singularform gebraucht, wie הבה Gen. II, 3 und 4, wo es gleich תנה ibid. 30, 26 ist, als auch im Plural, wie hier und in der Form הבה ibid. II, 7 und Exod. I, IO. Auch die Femininform kommt vor, wie הבי Ruth 2, I5, für die aber auch הבה vorkommt, 
ותדבירהא למא דונהא כמא סמעי אללה תעאלי אלהי האלהים ואדוני

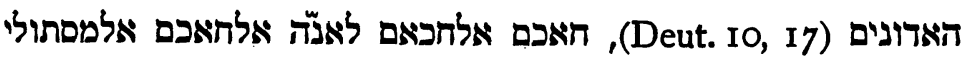

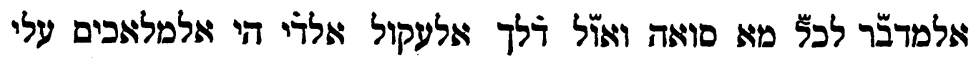

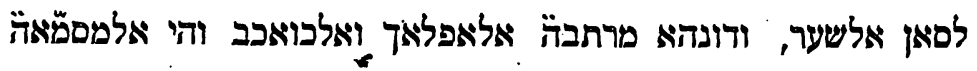

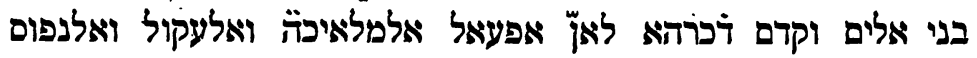

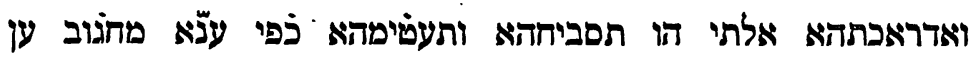

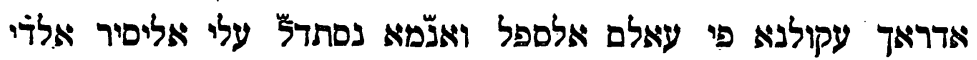

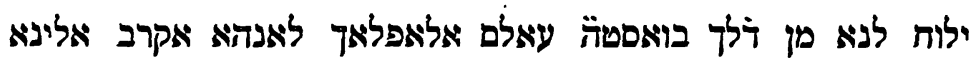

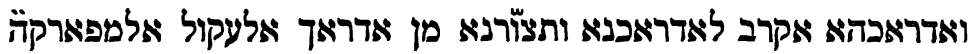

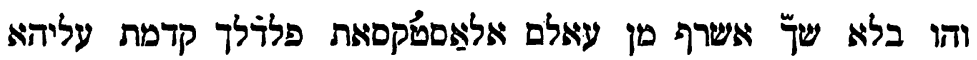

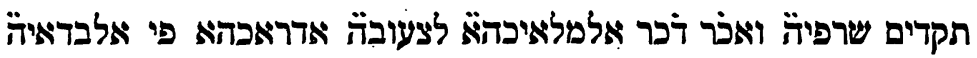

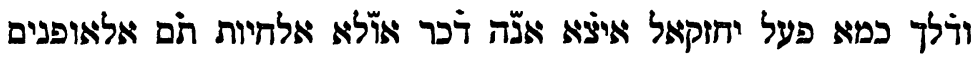

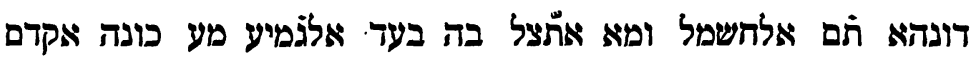

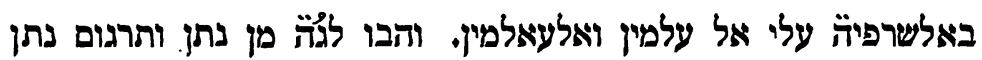

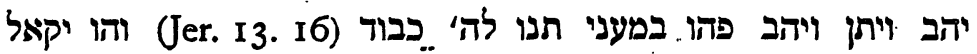

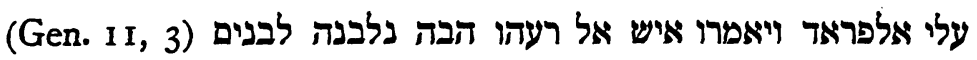

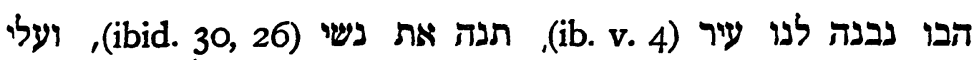

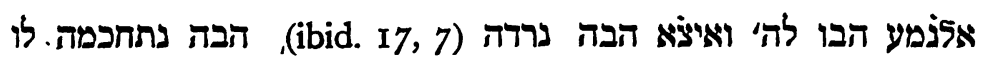
(Exod. I, Io)

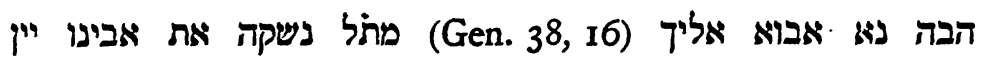

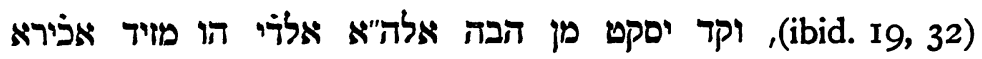

Deut. 10, 17 Maimûni's More Nebûchim Th. II Cap. 6, 67; auch David Kimhi a. 1. והמפרשים פירשו המומור דרך פשוטו על נפלאות הבורא הנראים באים

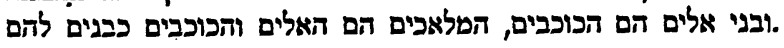

I Vgl. hierüber More Nebûchim Th. III Cap. 5 und die Bemerkungen von Munk, Guide, III p. 33 Note 2. - Was die Wendung עלמין ואלעאלטין bedeuten soll, ist mir unklar.

Zeitschrift $\varepsilon$ d. altest. Wiss. Jahrg. 23. II. 1903. 
wie Gen. 38, 16 gleich ibid. 19, 32. Auch fällt mitunter von הaseg, welches ein späterer Zusatz ist; so

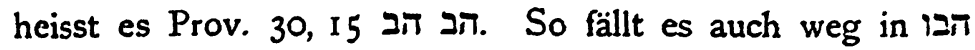
und הבי Eigentlich sollte die Form lauten Analogie von צודו, מדו, bei denen gleichfalls der erste Radical weggefallen ist, so dass dieses Wort hier im Vergleich mit den anderen durch das Kamez unregelmässig ist, ebenso wie die Form אפ Exod. 16, 23 mit Zere, die eigentlich Chatef-Pathach haben sollte, wie 16 ע, ח die Form eine ständige Apocopierung des ersten Radicals, des Jôd, da, wie bereits bemerkt, die Wurzel $2 \pi$ lautet. Dies finden wir nur noch erhalten in יהבך Ps. 55, 23, über welches jedoch verschiedene Ansichten herrschen, ob es ein Nomen ist, wie שקרך, שברך, oder ein Praeteritum, wie,

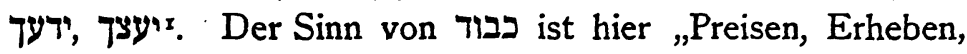
Verherrlichen", und dies wird durch den erläuternden Zusatz von iy bewirkt. Das Preisen und Verherrlichen ist zu verstehen im-Sinne von: Erfassen von Gottes Stärke und der Offenbarung seiner Allmacht und Weisheit und im Hinweis auf das Wunderbare seiner Thaten und das Erhabene seiner Eigenschaften ${ }^{2}$. v. 2. "Gebet dem Ewigen die Ehre seines Namens", d. h. rühmet und preiset ihn nach Maassgabe eures Erfassens der Grösse seines Wesens, die mit seinem Namen bezeichnet wird, d. h. nach dem, was hierzu gelangt von der reichlichen Ausströmung [des göttlichen Geistes] ${ }^{3}$ durch Vermittelung der erhabenen Intellecte, welche in Beziehung zu Gott gebracht werden, da sie ihm nahe sind und infolge ihrer hohen Stellung, und nach Maassgabe dessen, was sie hiervon erfassen. Wir haben auch bereits bemerkt, dass die Emanation des Intellectes כבוד genannt wird; deshalb ist auch hier zu שמו das Wort כבור hinzugefügt, d. h. der Name Gottes, und es ist zu verstehen, als lautete es: Erweist Gott Ehre durch Verherrlichung seines. 
ויקהל לעלוקה שתי בנות הב הב (Prov. 30, 15), וכרלך הי מסקושה:

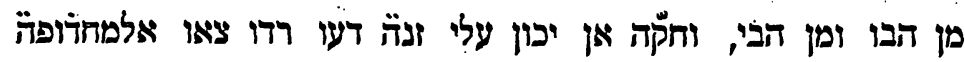

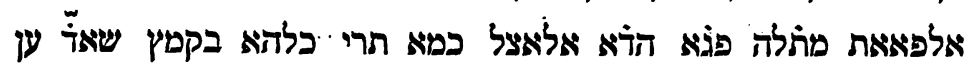

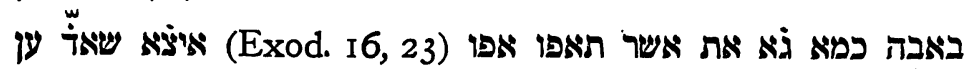

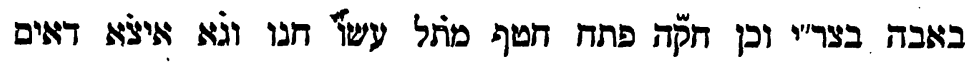

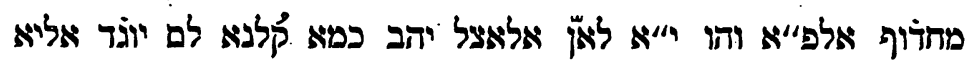

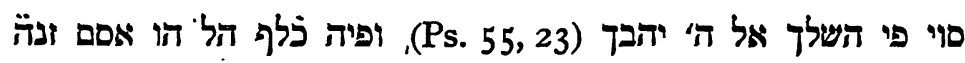

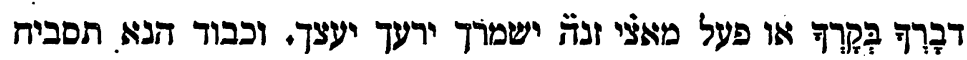

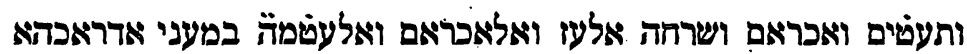
לעטימתה ומטהרה קדרתה וח[כמת]ה ודאזّה עלי גראבה אפעאלה

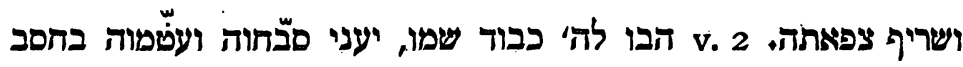

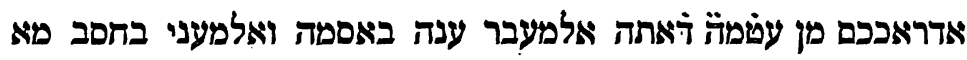

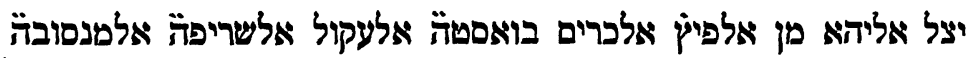

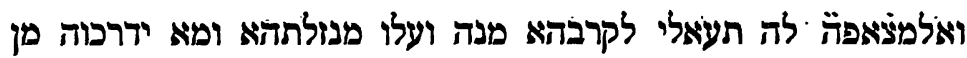

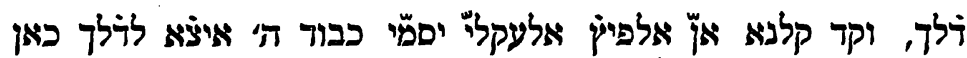

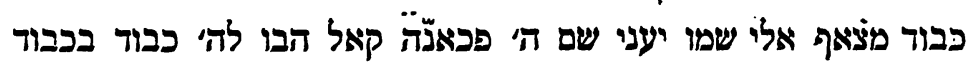

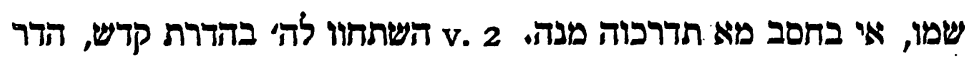

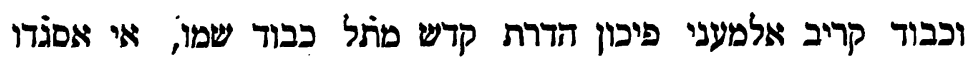

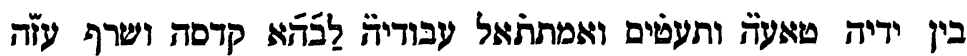

I Vgl. Hajû̀g. s. v. ed. Jastrow p. 45, wo beide Ansichten als möglich angeführt werden, und auch 7 T' als Beispiel vorkommt. Saadia a. 1. (ed. Baron p. VII) übersetzt es mit ךל̧̧̧ת. ,deine Last", vgl. ibid. p. 60 Anm. 10. Die Rg. 79 bei IG Wb. 277 hat ךיעמי

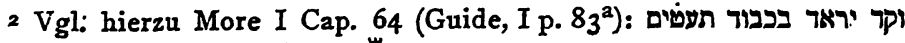

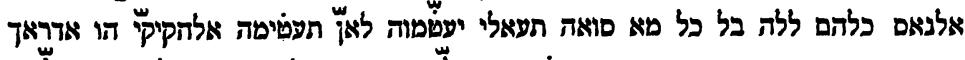

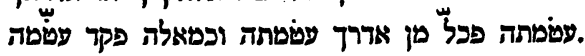

3 Über פיץ vgl. Guide des Egarés I p. 244 Note, II. p. 102 Anm. 2. 
Namens, d. h. durch das, was ihr von'seinem Wesen erfasset. „Beuget euch vor Gott in heiliger Verehrung“. וזר und כבוד sind sinnverwandt, so dass ähnlich wie כבוד שמו ist, d. h. beuget euch vor ihm in Gehorsam, in Verherrlichung und im Streben durch dienende Anbetung vor dem Glanze seiner Heiligkeit, der Erhabenheit seiner Macht und der Reinheit ${ }^{x}$ des von ihm Ausströmenden, das zu euch gelangt durch Vermittelung der Welt der Intellecte, die auch הוד הדר , כוד genannt wird, wie auch vom Menschen dieselben Ausdrücke gebraucht werden. Es wird auch von der Welt der Sphären und der Sterne von ihrem Gehorsam, ihrer Anbetung und ihrem Erfassen der Ausdruck des Beugens gebraucht, wie in Neh. 9, 6. Der Sinn ist dort, dass sie belebt sind ${ }^{2}$, Gottes Wesen erfassen, es verherrlichen und Gott gehorchen, in betreff dessen, dass er von ihnen verlangt die Leitung der niederen Welt, und gemäss des Guten und des Nutzens, der zu uns durch ihre Vermittelung gelangt, so dass sie offenbar Gott preisen, von seiner Macht sprechen, durch das, was uns offenbart wird von ihren Einflüssen; sie selbst sind erhaben durch seine gewaltige Weisheit, durch das, was uns aufgedeckt wird von ihrer Macht und ihrer Führung, die sie kenntlich machen in den von ihnen ausgehenden Wirkungen, wie es in der Erklärung von Ps. 19, 2 ausgeführt wurde 3 . Hierzu kommt noch, dass sie an und für sich auch erfassen Gottes Macht und ihn preisen wegen der so ausserordentlichen Erhabenheit seines Wesens und der hohen Stufe seiner Pracht und Würde. v. 3. Hiermit soll hingewiesen werden auf die Emanation, die vermittelst der Sphären auf die Welt der niederen Wesen gelangt. Das erste, was hierdurch zu Tage tritt, ist die gleichmässige Mischung der Elemente, das Aufsteigen der Dünste von der Feuchtigkeit, die sich sammelnden Gewässer, und als Folge hiervon die Gestaltung der Meteore[?] $4 \ldots$. 
ותנזיה פיצה הלואצל אליכם בואםטה עאלם הלעקול אלמםמי איציצה

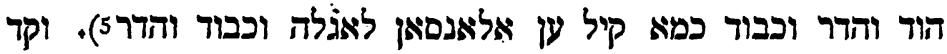

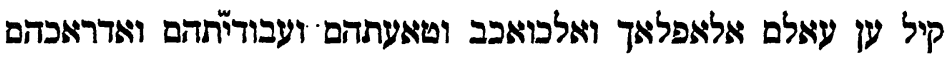

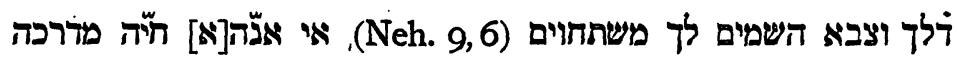

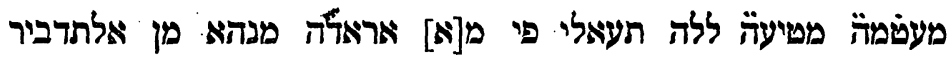

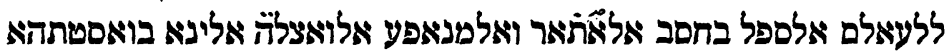

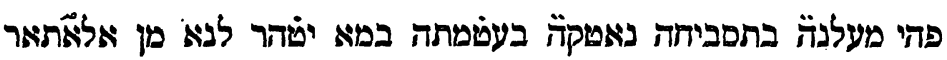

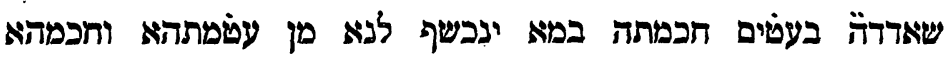
מוגדהא באלאפעאל אלציהדרה ענהא עלי מא תבין פי מומור השמים

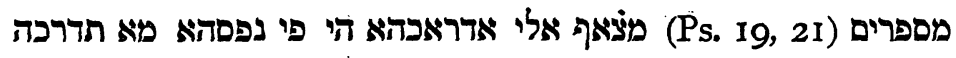

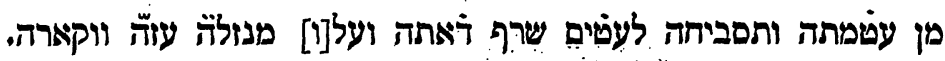
v. 3

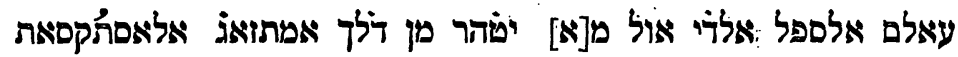

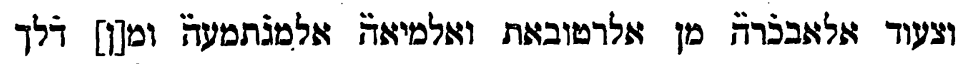

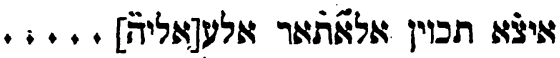

I So glaube ich hier am besten תמוזה wiederzugeben.

2 Vgl. hierzu More II, 5 .

3 Vgl. gleichfalls ibid.

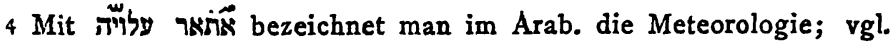
Munk, Guide des Egarés II p. 421 Note 1. Maimuni selbst nennt sie an der entsprechenden Stelle in II, 30 (p. 692 Z. I.) blos הึתאר. Ob Tanhûum hier dies gemeint hat, ist mir nicht ganz gewiss.

5 Unsere Vorlage hat והדרו; gemeint ist wohl jedenfalls der Vers Ps. 8,6 . 